\title{
THE CONCLUSIVE PRESUMPTION SHUFFLE
}

\author{
Bruce L. Ackerman $\dagger$
}

In recent years the United States Supreme Court has employed a conclusive presumption analysis as one method of adjudicating cases involving fifth or fourteenth amendment claims. ${ }^{1}$ The doctrine proscribes certain laws and regulations that place individuals in disadvantageous categories without giving them some opportunity to demonstrate that they do not belong there, ${ }^{2}$ but does not reach the question whether the underlying categorization is itself unconstitutional.

This limited, procedural reach of the test may have appealed to many of the Justices in some potential equal protection cases; protective procedural requirements generally do not restrict government actions with the finality attending a substantive constitutional invalidation. Further, as the Court moved toward an increasingly flexible-if open ended-“new reasonableness" approach to substantive equal protection adjudication, ${ }^{3}$ the conclusive presumption analysis may have appeared to provide a more manageable basis for review.

† B.A. 1968, Haverford College; J.D. 1971, Yale University. Executive Assistant to the Treasurer of New Jersey. Member, New Jersey Bar.

The author wishes to thank George Lefcoe and William Bishin of the University of Southern California Law Center and Tom Kleven of Texas Southern University School of Law for their helpful contributions to the early development of this Article and Gary Schwartz of the University of California at Los Angeles School of Law for his comments on a later draft.

${ }^{1}$ See, e.g., Turner v. Department of Employment Security, 423 U.S. 44 (1975) (per curiam); Weinberger v. Salfi, 422 U.S. 749 (1975); Cleveland Bd. of Educ. v. LaFleur, 414 U.S. 632 (1974); United States Dep't of Agriculture v. Murry, 413 U.S. 508 (1973); Vlandis v. Kline, 412 U.S. 441 (1973); Stanley v. Illinois, 405 U.S. 645 (1972); Bell v. Burson, 402 U.S. 535 (1971).

${ }^{2}$ See text accompanying notes 35-110 infra.

${ }^{3}$ See text accompanying notes 75-82 infra. For discussions of this more flexible equal protection analysis applied by the Supreme Court, see Gunther, The Supreme Court 1971 Term-Foreward: In Search of Evolving Doctrine on a Changing Court: A Model for a Newer Equal Protection, 86 HaRv. L. Rev. 1 (1972); Lefcoe, The Public Housing Referendum Case, Zoning, and the Supreme Court, 59 CaL. L. Rev, 1384 (1971); Note, Boraas v. Village of Belle Terre: The New, New Equal Protection, 72 Mich. L. Rev. 508 (1974); Note, Legislative Purpose, Rationality, and Equal Protection, 82 YALE L.J. 123 (1972). 
Critics, however, called attention to troublesome problems. ${ }^{4}$ Some charged that the full procedural reach of the conclusive presumption doctrine would paralyze legislatures and agencies by destroying their ability to administer programs economically. ${ }^{5}$ Others criticized the doctrine as providing procedural masks for substantive rulings. ${ }^{6}$ Even when the doctrine is recognized as an expression of procedural due process, the question arises whether, under a conclusive presumption review, the absence of an individualized factfinding process in establishing or applying a generalized legislative classification always will render a law vulnerable to a procedural challenge. ${ }^{7}$ Might not laws generally accepted as legitimate, such as minimum age requirements for driving or mandatory retirement age laws, succumb to this potentially expansive doctrine?

Eventually, these concerns impressed the Court sufficiently to permit Justice Rehnquist, in Weinberger $v$. Salfi, ${ }^{8}$ to author a majority opinion claiming that all the conclusive presumption cases actually had been decided on other grounds. Within five months of Justice Rehnquist's repudiation of the doctrine, however, a six-member majority again made use of conclusive presumption analysis in Turner v. Department of Employment Security. ${ }^{9}$ Only Justice Rehnquist dissented on the merits. ${ }^{10}$ Turner seems to assure the doctrine a measure of permanence while providing a basis for limiting the reach of conclusive presumption review. ${ }^{11}$ It does not, however, answer all questions concerning the doctrinal status of conclusive presumption analysis. Indeed, it may complicate matters by appearing to merge substantive and procedural due process principles. ${ }^{12}$

This Article will examine the procedural and substantive

${ }^{4}$ See Tribe, The Supreme Court 1972 Term-Foreward: Toward a Model of Roles in the Due Process of Life and Law, 87 Harv. L. Rev. 1, 8 n.41, 49 n.224 (1973); Note, The Irrebuttable Presumption Doctrine in the Supreme Court, 87 HARv. L. Rev. 1534 (1974); Note, The Conclusive Presumption Doctrine: Equal Process or Due Protection?, 72 Мrch. L. Rev. 800 (1974); Comment, Constitutional Law: Court Substitutes Conclusive Presumption Approach for Equal Protection Analysis, 58 MinN. L. Rev. 965 (1974); Note, Irrebuttable Presumptions: An Illusory Analysis, 27 STAN. L. Rev. 449 (1975).

${ }^{5}$ See, e.g., Comment, supra note 4, at 976-77.

${ }^{6}$ See, e.g., Note, The Conclusize Presumption Doctrine: Equal Process or Due Protection?, supra note 4 , at $823-24$.

${ }^{7}$ But see text accompanying notes 169-71, 221-73 infra.

8422 U.S. 749 (1975).

9423 U.S. 44 (1975) (per curiam).

1" Id. at 47 (Rehnquist, J., dissenting).

1 See text accompanying notes 67-70 infra.

${ }^{12}$ See text accompanying notes 72-86 infra. 
issues raised by the conclusive presumption decisions, focusing the discussion on two central themes. It will first identify the basic characteristics of adjudicatory decisionmaking and explain how the procedural safeguards already applied to agency adjudications can and should be extended to certain statutory and administrative classifications that function as conclusive presumptions. This analysis, which assays the highlights of the $\mathrm{Su}$ preme Court's procedural due process rulings, will be based more on the legislative and administrative factors that define a governmental decision as "adjudicatory" than on the customary due process code language of protected "property" and "liberty" interests.

Secondly, this Article will propose a manageable and coherent procedural doctrine for analyzing conclusive presumption claims and demonstrate that such a doctrine has major operational significance. An assessment of the Court's recent formulation of conclusive presumption theory, which uses "new reasonableness" principles to invalidate certain conclusive presumptions, reveals a formula for review that is inadequate for remedying all unnecessary and unfair conclusive presumptions. A serviceable and restrained procedural doctrine, however, can achieve proper utilization of fair procedures in conclusive presumption cases that would not be reached by an alternative new reasonableness review.

\section{A Procedural Due Process Foundation for Conclusive Presumption Analysis}

\section{A. The Elements of Adjudication}

The origin of the procedural analysis that has shaped the development of the conclusive presumption doctrine lies in federal court decisions reviewing adjudicative practices by administrative agencies. ${ }^{13}$ Once an interpretation of general application for a particular legal standard is announced, the final decision on whether a party receives or keeps a government benefit rests on a finding of fact, relatively unaffected by discretionary policy judgments. An agency adjudicates when it applies discrete cri-

${ }^{13}$ See generally 1 K. Davis, Administrative Law Treatise $\$$ 7.01-.20 (1958 \& Supp. 1970); K. Davis, Administrative Law of THE 70's $\$ \$ 7.00-.11$ (1976); Friendly, "Some Kind of Hearing," 123 U. PA. L. REv. 1267, 1267-70 (1975); Pederson, Formal Records and Informal Rulemaking, 85 YALE L.J. 38, 38-44 (1975); Note, Procedural Due Process in Government-Subsidized Housing, 86 HARv. L. Rev. 880, 897-98, n.89. 
teria contained in existing statutory or agency standards to the facts it has gathered. When such an adjudicatory situation is identified, principles of due process require the use of fair procedures in the application of the relevant legal criteria.

To apply the protective principles of procedural due process to adjudicatory proceedings, the Court has spoken in terms of protected "liberty" and "property" interests. Under this analysis, an interest is protected only if it constitutes a legal "entitlement"14 or is the result of a "legitimate reliance." ${ }^{15}$ The legisla-

${ }^{14}$ E.g., Goldberg v. Kelly, 397 U.S. 254, 267 (1970) (welfare benefits characterized as statutory entitlements).

${ }^{15}$ Perry v. Sindermann, 408 U.S. 593 (1972), provides an example of a protected property interest. In Perry, the Supreme Court held that Sindermann was entitled to a hearing prior to his dismissal as a teacher if he could demonstrate that he enjoyed de facto tenure status by virtue of his eleven years of teaching. Id. at 594, 599, 600. To dismiss a tenured teacher-that is, one who had an "entitlement" to remain on the faculty-the college that had been employing him would be obligated to "show cause" for his dismissal. Id . at 602-03. The obligation to make such a showing, requiring findings of fact, presents an adjudicatory situation.

On the other hand, when confronted with a discharged employee who could claim no entitlement to a factual determination, the Court did not call for due process protections. In Board of Regents of State College v. Roth, 408 U.S. 564 (1972), the Supreme Court allowed a state college to terminate a one year teaching appointment after the teacher's first year at the college without holding a predismissal hearing or providing other procedural safeguards. Unlike Sindermann, Roth could claim no tenured status. The Court therefore considered the new employee rehiring decision raised in Roth to be a proper subject for discretionary decisionmaking.

In Morrissey v. Brewer, 408 U.S. 471 (1972), the Court cited "legitimate reliance" as the basis for requiring the government to use protective procedures prior to the termination of a liberty interest. Chief Justice Burger observed that a parolee facing revocation "has relied on at least an implicit promise that parole will be revoked only if he fails to live up to the parole conditions." Id. at 482 . To make such a demonstration of nonadherence to parole standards, fact finding is necessary.

The Supreme Court in Roth also indicated that individuals are entitled to fair procedures prior to certain governmental actions that deprive them of liberty interests defined in terms of community standing and ability to find employment. 408 U.S. at $\mathbf{5 7 3}$. In these cases, it is a governmental charge of wrongful conduct or a governmental action raising the implication of such wrongful conduct that harms the liberty interest in reputation. Although a requirement of fair factfinding would avoid or minimize the improper imposition of reputational damage, the Court has limited its procedural protection to certain especially onerous forms of reputational damage. See, e.g., Paul v. Davis, 96 S. Ct. 1155, 1158-66 (1976). Since reputational damage is caused by an ostensibly objective determination of fact by a government, the Court could have characterized all governmentally caused reputational damage as "protected" and then applied a balancing test to limit procedural requirements to the more serious forms of reputational harm. Instead, the Court apparently is saying that an individual whose reputation is at stake can justifiably expect the government to employ fair factfinding procedures only if the government's actions will invite the imposition of especially harsh community sanctions. See 408 U.S. at 572-75; Paul v. Davis, 96 S. Ct. at 1166.

In Bishop v. Wood, 96 S. Ct. 2074 (1976), the Court reduced the scope of the protected liberty interest identified in Roth by refusing to require procedural safeguards when the governmental entity involved does not disclose publicly the reasons for an 
tive and agency programs that give rise to entitlements and reliance are those that employ the kind of discrete criteria that call for individualized factfinding. By identifying interests that qualify for procedural protection in this way, the Court has tailored the scope of its due process doctrine to fit those situations in which factfinding, not discretionary policy judgment, governs the allocation and continuation of a government benefit; ${ }^{16}$ that is, those situations involving some form of adjudicatory decisionmaking.

Typical of the kind of statutory provision that is subject to the fair adjudication requirement is one providing that a government employee may be dismissed only for "cause." Such a provision was at issue in Arnett $v$. Kennedy, ${ }^{17}$ in which six Justices, three concurring in the result and three dissenting, ${ }^{18}$ agreed that although a full trial-type hearing was not required, fair factfinding procedures were prerequisites to a final government decision to terminate employment.

The identification of a protected interest in Arnett is especially impressive because the applicable statute detailed specific procedures for the government to apply when dismissing an employee for cause. For Justice Rehnquist, joined by Chief Justice Burger and Justice Stewart, the statute's inclusion of specific procedures foreclosed any further judicial consideration of the fair process question. ${ }^{19}$ Justice Rehnquist concluded that a government employee has no right to more expansive employment termination procedures than those prescribed by statute. Under this analysis, statutorily specified procedures condition the nature of the property or liberty interest created by the statute.

employee dismissal. Even if the government's reasons were based on false information and were potentially damaging to the employee's reputation, nondisclosure would preclude such damage, according to the Court. Therefore, no constitutionally protected liberty interest was infringed upon. Id. at 2080. See also Paul v. Davis, 96 S. Ct. 1155 (1976); The Supreme Court, 1975 Term, 90 HARv. L. Rev. 56, 86-104 (1976).

${ }^{16}$ In addition to Perry v. Sindermann, 408 U.S. 593 (1972); Board of Regents of State College v. Roth, 408 U.S. 564 (1972); Morrissey v. Brewer, 408 U.S. 471 (1972), Goldberg v. Kelley, 397 U.S. 254 (1970), provides a clear example of such a situation. In Goldberg, the Supreme Court ordered a hearing for welfare recipients prior to termination of their welfare aid. Under the Social Security Act, eligible individuals are entitled to welfare benefits, 42 U.S.C. \$ 602(a)(10) (1970); see Townsend v. Swank, 404 U.S. 282 (1971); King v. Smith, 392 U.S. 309 (1968). Since the welfare program involves categorical aid, with termination contingent on nonadherence to particular program conditions, a termination proceeding clearly is an adjudicatory affair.

17416 U.S. 134 (1974).

${ }^{18}$ See text accompanying notes 19-21 infra.

19416 U.S. at 151-52. 
Six members of the Arnett Court rejected this conception of due process. ${ }^{20}$ They focused instead on the statute's creation of a government benefit tied to objectively ascertainable facts. At the core of this approach is the principle that when application of a statutory benefit category calls for objective factfinding, due process demands an appropriate measure of procedural fairness in determining the relevant facts-regardless of the procedures created by the statute granting the benefit. ${ }^{21}$ The six disagreed on the "appropriate" measure in the case before them; three found the statutory procedures adequate, ${ }^{22}$ three did not. ${ }^{23}$

A primary virtue of the six-Justice plurality approach in Arnett is that it forces a legislature to grapple directly with the decision whether to allocate government benefits in accordance with relatively objective factual determinations or instead by more open-ended, discretionary judgments. At the same time, this approach does not unduly confine legislative action. If a legislature decides that public officials should be free to make certain decisions without adhering to fair, and perhaps confining, factfinding procedures, it can authorize more discretionary standards for decisionmaking. ${ }^{24}$ A legislature causes needless confusion and frustration, however, when it provides for the apportionment and termination of government benefits on the basis of ascertainable facts, yet authorizes the use of procedures

${ }^{20} I d$. at 164 (Powell and Blackmun, JJ., concurring); id. at 171 (White, J., concurring); id. at 206 (Brennan, Douglas, and Marshall, JJ., dissenting).

21 Compare this with Bishop v. Wood, 96 S. Ct. 2074 (1976), discussed in notes 108-10 \& accompanying text infra. Bishop may suggest that the Court is moving away from the Arnett plurality's concept of fair adjudication.

${ }^{22}$ See 416 U.S. at 164 (Powell and Blackmun, JJ., concurring); id. at 171 (White, J., concurring).

${ }^{23}$ See id. at 206 (Brennan, Douglas, and Marshall, JJ. dissenting).

${ }^{24}$ See text accompanying notes 14-16 supra.

A fair adjudication analysis that focuses on entitlement and reliance should not be viewed as approving all forms of discretionary government decisionmaking that may accompany the creation of certain statutory and administrative categories. Where appropriate to control unacceptable governmental arbitrariness, the courts can properly direct agencies to articulate standards as the basis for allocating benefits. For example, courts have required agency specification of standards for benefit allocations characterized as follows: (1) the applicable statute has announced eligibility criteria calling for objective factual determinations, (2) the availability of the benefit is inadequate for allocating it to all eligible applicants, and (3) the applicable statute admits some discretionary policy judgment for rationing the limited benefit. See Holmes v. New York City Housing Authority, 398 F.2d 262 (2d Cir. 1968); Hornsby v. Allen, 326 F.2d 605 (5th Cir. 1964). Sometimes imposition of a standards requirement on agencies could push additional agency decisionmaking into the adjudicatory mold. See generally Board of Regents of State College v. Roth, 408 U.S. 564, 587 (1972) (Marshall, J., dissenting). But see also text accompanying notes 241-47 infra. 
that clearly are inadequate for determining those facts fairly. An adjudicatory decision, such as employment termination, made without any resort to fair factfinding procedures, often will appear arbitrary and unjust. Notwithstanding Justice Rehnquist's analysis, the employee in such a case has been working under a statutory "entitlement" that explicitly states that he can keep his job as long as he complies with certain performance requirements. ${ }^{25}$ To preclude untoward government behavior in these cases, procedural due process should require a government to employ fair procedures.

\section{B. Programmatic Limitations on Procedural Safeguards}

Once a court decides that an interest qualifies for due process safeguards, it then must determine how much process is due. In order to avoid unnecessary interference with the administration of public programs, the courts have fashioned a balancing test for making this latter determination. The Supreme Court set forth the elements to be balanced in Mathews v. Eldridge $:^{26}$

[F]irst, the private interest that will be affected by the official action; second, the risk of an erroneous deprivation of such interest through the procedures used, and the probable value, if any, of additional or substitute procedural safeguards; and finally, the Government's interest, including the function involved and the fiscal and administrative burdens that the additional or substitute procedural requirement would entail. ${ }^{27}$

In Mathews, "due process" did not require an adjudicatory hearing prior to the termination of disability benefits under the Social Security Act. ${ }^{28}$ In contrast, the Court held in Goldberg $v$. Kelly ${ }^{29}$ that such an adjudicatory hearing would be required before terminating welfare benefits under the federal-state AFDC programs. ${ }^{30}$

Thus, viewed in conjunction, Mathews and Goldberg indicate

${ }^{25}$ See 416 U.S. at 151-52 (opinion of Rehnquist, J.); id. at 166 (Powell, J., concurring); id. at 209-10 (Marshall, J., dissenting).

26424 U.S. 319 (1976).

27 Id. at 335 .

${ }^{28} 42$ U.S.C. $\$ 423$ (1970).

${ }^{29} 397$ U.S. 254 (1970).

30 42 U.S.C. $\S \S 601-10$ (1970). 
that even slight changes in context may yield varied results under this balancing test if the relative weights of the individual interest and governmental program needs and limitations are perceived to be different. ${ }^{31}$ Indeed, in some cases the courts have accepted partial or no procedural safeguards because certain programs cannot function effectively unless procedural protection is truncated. ${ }^{32}$ The appeal of this balancing test is that while substantial interests of private persons are to some degree protected, the decision that some process is due does not necessarily lead to judicial imposition of undue restrictions on the ability of legislative and administrative bodies to construct and administer programs. ${ }^{33}$

${ }^{31}$ Three recent cases demonstrate the Supreme Court's continuing sensitivity to the possibility that judicially mandated procedures will improperly frustrate significant policy objectives. In Arnett v. Kennedy, 416 U.S. 134, 154 (1974), the six-member plurality accepted factfinding procedures that did not include a predismissal trial-type hearing as sufficient for dismissing an OEO nonprobationary employee. Justices Powell and Blackmun, who cast the deciding votes, approved of the OEO's action because the government's interest in the "maintenance of employee efficiency and discipline," $i d$. at 168 (Powell, J., concurring), outweighed the interest of the employee in avoiding "a temporary interruption of income." Id. at 169 (Powell, J., concurring).

In Goss v. Lopez, 419 U.S. 565 (1975), the Court required certain procedural protection for public school students prior to their suspension from school for disciplinary reasons; but, in deference to the viable and efficient administration of the educational facility, concluded that the full range of adjudicatory protections was not appropriate.

Similarly, in Wolff v. McDonnell, 418 U.S. 539 (1974), the Court sought to accommodate program needs with fair process by providing a limited range of procedural protections for prisoners facing either the loss of good-time credit or solitary confinement. The Court held that a prisoner was entitled to prior written notice, a written statement of findings by the adjudicatory body, and the opportunity to call witnesses and present documentary evidence in his own behalf, if doing so would not jeopardize institutional safety or correctional goals. Id. at 564, 566. The Court held, however, that the prisoner was not entitled to retained or appointed counsel, or to confront accusers and cross-examine witnesses. $I d$. at 568,570 .

For more on the balancing test as it relates to programmatic constraints, see Friendly, supra note 13, at 1278; Note, supra note 13, at 897-98.

32 The Goldberg opinion cited with approval decisions allowing agencies to take adverse action without first affording basic procedural protections to those affected. 397 U.S. at 263 n.10. For example, in North Am. Cold Storage Co. v. Chicago, 211 U.S. 306 (1908), agents of the city of Chicago, without first providing protective adjudicatory procedures, seized food thought to be unfit for human consumption. The Court reasoned that if the government is to implement effectively its legitimate policy of protecting citizens from dangerous food, time-consuming procedures before seizure are inappropriate. For other examples of judicially approved summary action, see Ewing v. Mytinger \& Casselberry, Inc., 339 U.S. 594 (1950) (seizure of mislabeled vitamin product); R. A. Holman \& Co. v. SEC, 299 F.2d 127, cert. denied, 370 U.S. 911 (1962) (suspension of exemption from stock registration requirement).

${ }^{33}$ This is not to suggest that the balancing test is characterized by enormous ease of application or consistency of result. Compare Fuentes v. Shevin, 407 U.S. 67 (1972) (prejudgment replevin laws allowing creditors to seize chattels without first affording prior notice and opportunity to be heard held unconstitutional), with Mitchell v. W. T. Grant 


\section{The Supreme Court Conclusive Presumption Decisions}

\section{A. Procedural Standards for Statutory Categories}

In due process terms, a statute is constitutionally defective if it contains factfinding procedures that are inadequate for making a factual determination that the statute requires. ${ }^{34}$ One legislative technique that may deny fair factual determinations in the allocation of government benefits is the creation of entitlement categories defined in part by a conclusive presumption of certain facts. To invalidate a legislative category on conclusive presumption grounds, a court must be able to identify a legislative substitution of a presumed fact for a fair determination of fact. Thus, in the 1932 case of Heiner v. Donnan, ${ }^{35}$ the Supreme Court characterized section 302(c) of the Revenue Act of $1926^{36}$ as a conclusive presumption. ${ }^{37}$ The Act, which imposed an estate tax on all gifts made in contemplation of death, provided that gifts made within two years of the decedent's death shall "be deemed and held to have been made in contemplation of death." 38 The Court held that this provision violated due process because "it constitutes an attempt by legislative fiat, to enact into existence a fact which here does not, and cannot be made to, exist in actuality ...."39 The Court had no difficulty concluding that Congress had attempted to avoid a fair factfinding process because the statute expressly announced that the challenged provision was designed to serve as a surrogate for individualized factual determinations.

Conclusive presumption adjudication began in earnest in

\footnotetext{
Co., 416 U.S. 600 (1974) (procedure permitting trial judge to order sequestration of property without granting prior notice and opportunity to be heard held constitutional). The four dissenters in Grant, Justices Stewart, Douglas, Brennan, and Marshall-members of the Fuentes majority-were unable to perceive any constitutionally significant differences between the procedures involved in the two cases. 416 U.S. at 629-36 (Stewart, J., dissenting). Inherent in the use of a flexible balancing test is the possibility that a changed Court majority will seize upon a slight factual difference to justify a result at variance with previous decisions. Such a change in the personnel on the Court may explain the movement from Fuentes to Mitchell and from Goldberg to Matthews. See id. at 635.

${ }^{34}$ See notes $26-33$ supra \& accompanying text.

35285 U.S. 312 (1932).

${ }^{36}$ Ch. 27,44 Stat. 70 (1926) (current version at I.R.C. $\$ 2035(b)$ ).

37285 U.S. at 324.

${ }^{38}$ Ch. 27, 44 Stat. 70 (1926).

${ }^{39} 285$ U.S. at 329.
} 
1971. In Bell v. Burson, ${ }^{40}$ the Supreme Court examined legislative purpose to determine whether certain statutory provisions were designed to avoid fair factual determinations. Bell involved a Georgia statute requiring uninsured motorists involved in automobile accidents either to secure a release from liability or post security in the amount of damages claimed against them. ${ }^{41} \mathrm{Re}-$ gardless of whether there was any evidence that the driver would be held liable, the statute mandated the suspension of an uninsured motorist's license if he or she failed to comply with its security requirements. ${ }^{42}$ Georgia argued that a hearing on the question of possible liability was unnecessary because fault and liability were not part of the statutory scheme. ${ }^{43}$ This defense failed. Speaking for the Court, Justice Brennan stated:

'[W]e look to substance, not to bare form, to determine whether constitutional minimums have been honored.' ... And looking to the operation of the State's statutory scheme, it is clear that liability, in the sense of an ultimate judicial determination of responsibility, plays a crucial role in the Safety Responsibility Act. If prior to suspension there is a release from liability executed by the injured party, no suspension is worked by the Act. ... Thus, we are not dealing here with a no-fault scheme. ${ }^{44}$

The Court then ordered Georgia to provide "a forum for the determination of the question whether there is a reasonable possibility of a judgment being rendered against [the licensee] as a result of the accident." 45

Subsequently, the Supreme Court invalidated other statutory schemes as establishing conclusive presumptions in violation of procedural due process. In Stanley $v$. Illinois, ${ }^{46}$ the Court rejected Illinois' conclusive statutory presumption that unwed fathers are unfit to raise their children. ${ }^{47}$ Then, in Vlandis $v$. Kline ${ }^{48}$ the Court overturned Connecticut's statutory definition

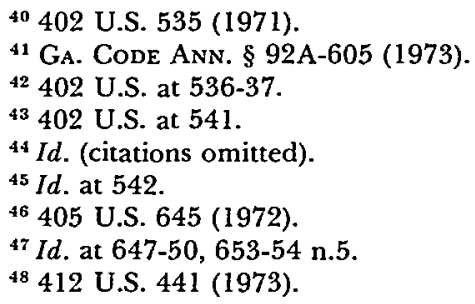


of residency used to charge out-of-state residents attending Connecticut public colleges tuition and fees higher than those charged in-state residents. The Court found that the Connecticut statute improperly created the conclusive presumption that students who had recently lived out of state were not Connecticut residents at any time during their Connecticut college education. Two weeks after deciding Vlandis, the Court struck down section 5(b) of the Food Stamp Act ${ }^{49}$ in United States Department of Agriculture v. Murry. ${ }^{50}$ The Court there held that section 5(b) created the conclusive presumption that households are not needy if they "contain persons 18 years or older who have been claimed as 'dependents' for federal income tax purposes by taxpayers who are themselves ineligible for food stamp relief." 51 At the end of this conclusive presumption invalidation spree, in Cleveland Board of Education v. LaFleur, ${ }^{52}$ the Court, citing its fresh precedents, held that school boards may not conclusively presume that a woman entering her fourth or fifth month of pregnancy is physically unable to teach. Similarly, the Court rejected rules conclusively presuming that after giving birth a woman will not be physically able to resume teaching until a specified number of months have passed.

\section{B. A Procedural Retreat}

Although LaFleur extended the string of conclusive presumption decisions, it also revealed that Justice Powell had abandoned his support for that mode of analysis. Concurring on equal protection grounds, ${ }^{53}$ he announced that he had become persuaded by the objections to the conclusive presumption doctrine raised by Justice Rehnquist in dissent. ${ }^{54}$ Apparently, other early supporters of the doctrine also began to share Justice Powell's concerns, for in Weinberger $v$. Salfi ${ }^{\mathbf{5 5}}$ Justice Rehnquist was able to speak for the Court in an opinion that repudiated conclusive presumption analysis.

In Salfi, the widow of a heart attack victim, who had died less than six months after their marriage, challenged the denial

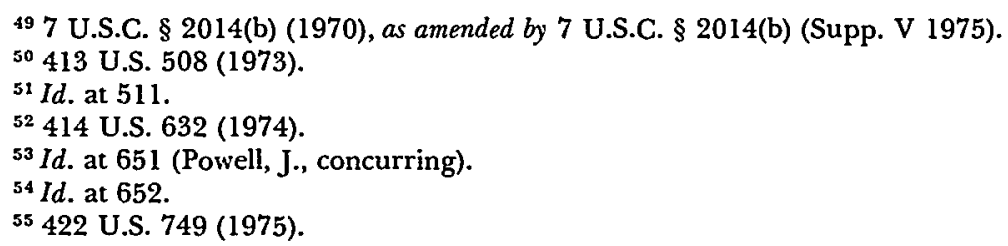


of social security benefits to herself and her daughter by a previous marriage. The Social Security Act provides insurance benefits for the spouse and children of a deceased wage earner only if they were related to the wage earner for at least nine months prior to the insured's death. ${ }^{56}$ The Secretary of HEW defended this limitation as a means for preventing payments to the survivors of sham marriages that were consummated only for the purpose of creating social security insurance beneficiaries. ${ }^{57}$ The Court, having accepted this rationale for the provision, ${ }^{58}$ easily could have followed the district court's invalidation of the duration requirement as a conclusive presumption. ${ }^{59} \mathrm{~A}$ six-member majority, however, upheld the nine-month requirement. For Justice Rehnquist, writing for the majority, categories effected by laws creating conclusive presumptions are to be judged by the standards applied to other legislative classifications; in most cases that standard is a reasonableness test. ${ }^{60}$ In applying that test in Salfi, although he recognized that the challenged provision was designed to avoid individualized determinations and would exclude some bona fide claimants, Justice Rehnquist concluded that "Congress could rationally choose to adopt such a course."61 Further, he feared that adherence to

56 42 U.S.C. \$ 416(c) \& (e) (Supp. V 1975).

57422 U.S. at $776-77$.

${ }^{58} I d$. at 780 .

${ }^{59}$ Salfi v. Weinberger, 373 F. Supp. 961 (N.D. Cal. 1974), rev'd 422 U.S. 749 (1975). The Act's legislative history supports this interpretation of the nine-month requirement. See 422 U.S. at 777-80.

60422 U.S. at $776-77$.

${ }^{61} I d$. at 781. It is not surprising that Justice Rehnquist would be in the forefront of an effort to discard the conclusive presumption doctrine. In Amett v. Kennedy, 416 U.S. 134 (1974), he had attempted unsuccessfully to reduce the reach of procedural due process. See text accompanying note 19 supra. Moreover, he had consistently opposed the Court's conclusive presumption decisions. See Cleveland Bd. of Educ. v. LaFleur, 414 U.S. 632, 657 (1974) (Rehnquist, J., dissenting); United States Dep't of Agriculture v. Murry, 413 U.S. 508, 522 (1973) (Rehnquist, J., dissenting); Vlandis v. Kline, 412 U.S. 441, 463 (1973) (Rehnquist, J., dissenting). Typifying the spirit of his position is the following excerpt from his dissent in LaFleur:

As The ChIEf Justice pointed out in his dissent last year in Vlandis $v$. Kline, 412 U.S. 441, "literally thousands of state statutes create classifications permanent in duration, which are less than perfect, as all legislative classifications are, and might be improved on by individualized determinations . . .." $I d$., at 462 . Hundreds of years ago in England, before Parliament came to be thought of as a body having general law making power, controversies were determined on an individualized basis without benefit of general law. Most students of government consider the shift from this sort of determination, made on an ad hoc basis by the King's representative, to a relatively uniform body of rules enacted by a body exercising legislative authority, to have been a significant step forward in the achievement of a civilized political society. It 
an individualized-determination rule in Salfi would turn the conclusive presumption doctrine "into a virtual engine of destruction for countless legislative judgments which have heretofore been thought wholly consistent with the Fifth and Fourteenth Amendments to the Constitution."62

Justice Rehnquist argued that the prior conclusive presumption rulings actually were decided on other grounds. He cited an "essential" interest in child rearing to explain Stanley" ${ }^{63}$ and referred to constitutional protections for "matters of marriage and family life" to justify the holding in LaFleur. ${ }^{64} \mathrm{He}$ attributed the invalidations of the food stamp eligibility requirement in Murry to a determination that there was no rational relationship between the eligibility criteria and any legitimate legislative goal. ${ }^{65}$ He made no mention of $B e l l$, and encountered considerable difficulty in distinguishing Vlandis. ${ }^{66}$

\section{Merging Procedure with Substance- A Doctrinal Consolidation?}

Justice Rehnquist's effort to expunge the conclusive presumption doctrine was undermined, however, in Turner v. Department of Employment Security, ${ }^{\mathbf{6 7}}$ a per curiam ruling that again included conclusive presumption analysis. At issue was a Utah statute rendering all pregnant women ineligible for unemployment benefits for a period starting twelve weeks before the expected date of childbirth and extending six weeks afterwards. ${ }^{68}$ The Court viewed the law as creating an invalid conclusive pre-

seems to me a little late in the day for this Court to weigh in against such an established consensus.

414 U.S. at 657-58 (Rehnquist, J., dissenting).

62422 U.S. at 772 . See generally text accompanying notes $4-8$ supra.

63422 U.S. at 771 (quoting Meyer v. Nebraska, 262 U.S. 390, 399 (1923)).

${ }^{64}$ Id.

${ }^{65} I d$.

${ }^{66}$ Justice Rehnquist characterized the holding in Vlandis in procedural terms: "[W]here Connecticut purported to be concerned with residency, it might not at the same time deny to one seeking to meet its test of residency the opportunity to show factors clearly bearing on that issue." Id. at 771. Perhaps Justice Rehnquist acknowledged the procedural basis for the Vlandis holding because of the form of the statute at issue. Because the statute expressly stated that determination of the residency of college applicants was its purpose, the procedure-avoidance objective was difficult to ignore. Although Justice Rehnquist's Salfi opinion rejects the conclusive presumption doctrine, his treatment of Vlandis might suggest an approval of conclusive presumption analysis for those easy cases in which the procedural objective of a challenged statute is explicit. See text accompanying notes 118-31 infra.

67423 U.S. 44 (1975) (per curiam).

68 Utah Code ANN. \& 3-4-5(h)(1) (1974). 
sumption because many women are in fact able to work during much of the statutory period. ${ }^{69}$

Turner suggests a restraining principle for conclusive presumption analysis: the requirement of individualized fact finding is triggered by the implication of a vital human interest. More clearly than in any previous opinion relying on the theory of conclusive presumptions, the Court tied the need for individualized determination to the identification of a constitutionally preferred interest-in Turner, the right to bear children. Said the Court: "The Fourteenth Amendment require[s] that unemployment compensation boards . . . must achieve legitimate state ends through more individualized means when basic human liberties are at stake."70

Procedural due process cases often have assessed the importance of the individual interest adversely affected by a challenged procedure, ${ }^{71}$ an assessment represented by a court's balancing the individual interest affected against the government's interest in employing an abbreviated procedure. ${ }^{72}$ Similarly, Supreme Court conclusive presumption decisions-even before Turner-had used language suggesting that substantive concerns were behind the results. Thus, in Stanley, the Court expressed its strong concern with preserving family integrity, ${ }^{73}$ while in LaFleur, it noted that "freedom of personal choice in matters of marriage and family life is one of the liberties protected by the Due Process Clause." 74

The equal protection overtones of these two decisions are consistent with the emergence in recent years of an equal protection analysis marked by increased flexibility. ${ }^{75} \mathrm{~A}$ "new reasonableness" test has made inroads on the more rigid two-tiered approach that either permissively accepts a classification justified by "some rational basis"76 or, alternatively, virtually assures invalidation by requiring a "compelling state interest" justification. ${ }^{77}$ When the Court has applied its new reasonableness test

69423 U.S. at 46 .

${ }^{70} \mathrm{Id}$. (1970).

${ }^{71}$ See, e.g., Goss v. Lopez, 419 U.S. 565 (1975); Goldberg v. Kelly, 397 U.S. 254

${ }^{2}$ See text accompanying notes 26-33 supra.

73405 U.S. at 651 .

74414 U.S. at 639.

${ }^{75}$ See note 3 supra \& accompanying text.

${ }^{76}$ See, e.g., McGowan v. Maryland, 366 U.S. 420 (1961).

${ }^{77}$ See, e.g., Shapiro v. Thompson, 394 U.S. 618 (1969). 
for reviewing legislative classifications, the identification of an important value that is threatened has triggered a somewhat heavier burden of governmental justification, though not the compelling state interest justification required under the stringent suspect classification ${ }^{78}$ or fundamental interest ${ }^{79}$ standards. Consequently, the Stanley focus on family integrity and the "precious" right to raise one's own children" suggests the possibility that a new reasonableness review was applied. The challenged practice in LaFleur centered on issues concerning childbearing-a "vital area of . . . constitutional liberty."81 Although neither the classification made nor the interest affected triggered the compelling interest standard of review in LaFleur, the Court appeared to apply a new reasonableness review as it concluded that there was no rational relationship between the state's goal of instructional continuity and the means employed to achieve it. ${ }^{82}$

It is not surprising that the childbearing interest at issue in LaFleur and Turner-as well, perhaps, as the child-rearing interest at issue in Stanley-triggered a new reasonableness review. These issues are closely related to questions involving sex discrimination, which have been attracting much of the Court's attention of late. ${ }^{83}$ The Court has attempted to redress grievances associated with sex classifications without ruling that such governmental distinctions are subject to the stringent suspect classification review standard. ${ }^{84}$

The limited conclusive presumption doctrine suggested by Turner would furnish the Court with a helpful addition to its new reasonableness test. In cases involving constitutionally preferred interests that do not warrant a fundamental interest/suspect classification review, the Court can require fair adjudication to protect the important interests in question. In the language of equal protection, this approach represents the maximum remedy for

${ }^{78}$ See Loving v. Virginia, 388 U.S. 1 (1967).

${ }^{79}$ See, e.g., Shapiro v. Thompson, 394 U.S. 618 (1969).

80 405 U.S. at 651 (quoting May v. Anderson, 345 U.S. 528, 533 (1953)).

81414 U.S. at 640.

$82 I d$. at $640-43$.

${ }^{83}$ See, e.g., Stanton v. Stanton, 421 U.S. 7 (1975); Frontiero v. Richardson, 411 U.S. 677 (1973); Reed v. Reed, 404 U.S. 71 (1971).

${ }^{84}$ See, e.g., Stanton v. Stanton, 421 U.S. 7 (1975). In part, the Court may fear that introduction of the suspect classification test into these cases will frustrate what it considers to be remedial legislation. See text accompanying notes 270-75 infra. 
correcting undesired over- and underinclusiveness. ${ }^{85}$ For cases involving sex classification, the individualized approach is especially appropriate because the Court has attacked certain sex distinctions as constituting unfair and inaccurate stereotypes. ${ }^{86}$ At the same time, this application of Turner-approaching conclusive presumption analysis from the perspective of current equal protection or substantive due process theory-is consistent with the Salfi rejection of fair adjudication theory as the primary basis for invoking the doctrine.

The predecessor of the analysis just suggested is Jimenez $v$. Weinberger. ${ }^{87}$ Jimenez involved section $216(\mathrm{~h})$ of the Social Security Act, ${ }^{88}$ which denied disability benefits to a certain class of illegitimate dependents born after a wage earner became disabled. Under that section and section $202(\mathrm{~d})(3)(\mathrm{A}),{ }^{89}$ an illegitimate child born after the disability has been sustained qualifies for benefits only if under state law the child is allowed to inherit from the wage earner, ${ }^{90}$ the illegitimacy resulted from "formal, nonobvious defects in [the] parents' ceremonial marriage,"91 or the child has been "legitimated in accordance with state law."92 Illegitimates falling into any one of these categories could receive benefits without any showing of actual dependency; all others were denied benefits regardless of actual dependency. This exclusionary rule was defended as a means of preventing spurious benefit claims by illegitimate children not genuinely dependent on a disabled parent. ${ }^{93}$

Conceding the legitimacy of this objective, ${ }^{94}$ Chief Justice Burger, speaking for an eight-member majority, concluded that the statutory exclusion of some after-born illegitimate children constituted a denial of equal protection because no rational basis existed for the distinction between the two classes of illegitimates. ${ }^{95}$ The exclusionary category made the Act underinclusive: some dependent children were excluded. Conversely, the other category made the Act overinclusive: some who were not

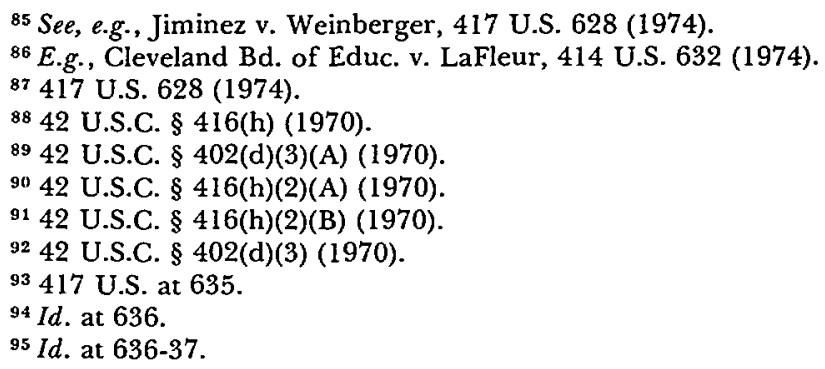


dependent were included. "Thus," argued the Chief Justice, "the two subclasses of illegitimates stand on equal footing, and the potential for spurious claims is the same as to both; hence to conclusively deny one subclass benefits presumptively available to the other denies the former the equal protection of the laws . . . ."96 Calling for a remedy characteristic of the conclusive presumption rulings, the Court remanded the case to afford the plaintiffs an opportunity to demonstrate the validity of their dependency. ${ }^{97}$

As Justice Rehnquist observed in dissent, ${ }^{98}$ the Jimenez majority effectively applied a conclusive presumption analysis. Insofar as discrete dependency criteria that could be satisfied by factual showings gave rise to a statutory entitlement to disability benefits, ${ }^{99}$ the majority opinion may be viewed in terms of the procedural due process rationale of the conclusive presumption doctrine. Because Jimenez dealt with classifications that disadvantaged illegitimate children, however, its approach also can be viewed as a first run of the new equal protection role for conclusive presumption analysis that was suggested by Turner. As in Turner, the Jimenez Court identified a classification that, although not "suspect" enough to require a compelling state interest justification, was sufficiently special to require more individualized determinations of benefits eligibility. ${ }^{100}$

The Supreme Court's subsequent decision in Mathews v. Lucas ${ }^{101}$ highlights the procedural analysis that the Jimenez majority had phrased in equal protection terms. Lucas upheld section 202(d) of the Social Security Act, ${ }^{102}$ under which "dependent" unmarried children are entitled to receive survivor's benefits upon the death of a parent. A child qualifies as a de-

${ }^{96} I d$. at 637.

s7 Id. at 637-38.

${ }^{98}$ Id. at 639 (Rehnquist, J., dissenting).

${ }^{99}$ See text accompanying notes 13-16 supra.

100 This approach offers the Court an escape from its uncertainty over whether to treat illegitimacy as a suspect classification. See Weber v. Aetna Casualty \& Surety Co., 406 U.S. 164 (1972) (invalidated a state workmen's compensation statute relegating unacknowledged illegitimate children to a lesser benefits status than that occupied by the deceased's legitimate children); Labine v. Vincent, 401 U.S. 532 (1971) (upheld a Louisiana statute allowing illegitimate children to inherit only if there were no surviving spouse or legitimate relatives); Levy v. Louisiana, 391 U.S. 68 (1968) (held that an interpretation of a Louisiana wrongful death statute denying recovery to illegitimate children invidiously discriminated against the illegitimate children in violation of the Equal Protection Clause).

101427 U.S. 495 (1976).

10242 U.S.C. $\S 402$ (d) (1970), as amended by 42 U.S.C. $\S 402$ (d) (Supp. V 1975). 
pendent if, at the time of the parent's death, the parent was living with the child or contributing to the child's support. ${ }^{103}$ The statute expressly presumes, however, that almost all legitimate children and some categories of illegitimate children are dependent. ${ }^{104}$ Most illegitimate children, on the other hand, must individually demonstrate a dependence upon the deceased parent.

Lucas does not raise the equal protection problem of underinclusivenesss highlighted in Jimenez. Although most illegitimate children who satisfy the criteria of dependency do not enjoy a presumption of eligibility, they may collect survivor's benefits by demonstrating the requisite facts. ${ }^{105}$ Under the provision of the statute questioned in Jimenez, those not presumed dependent were denied such an opportunity to demonstrate dependency. ${ }^{106}$ The challenged provision in Lucas, however, did present the same overinclusiveness as that in Jimenez; the Court nevertheless held the former to be constitutional. Consistent with this result the Jimenez remedy had addressed only the procedural inadequacies resulting in the statute's underinclusiveness. ${ }^{107}$ The primary principle that emerges from the two cases is that illegitimate children must be afforded the opportunity to demonstrate their dependency when a government program generally grants benefits to dependent children. As long as procedurally fair access to these benefits is provided, the Court will approve a statute also containing overinclusive categories that represent reasonable presumptions of dependent status.

Even while the Supreme Court has expanded the application of fair process principles in equal protection contexts, it has, in Bishop v. Wood, ${ }^{108}$ handed down a decision that implies limi-

10342 U.S.C. $\S 402(\mathrm{~d})(3)(1970)$.

${ }^{104}$ See id. Illegitimate children who have not been adopted are presumed to be dependent if they fall within one of the following categories:

(1) the child is entitled to inherit personal property from the insured parent under the applicable state intestacy law;

(2) the deceased parent prior to death (a) had gone through a marriage ceremony with the other parent, resulting in a purported marriage between them which, but for a nonobvious legal defect, would have been valid, or (b) had acknowledged in writing that the child was his, or (c) had been decreed by a court to be the child's father, or (d) had been ordered by a court to support the child because the child was his. 427 U.S. at 498-99.

110427 U.S. at 512.

${ }^{106}$ See text accompanying notes 88-93 supra.

${ }^{1117}$ See 417 U.S. at 637-38.

108426 U.S. 341 (1976). 
tations for the use of procedural due process theory to proscribe statutorily created conclusive presumptions. Bishop upheld the dismissal, without due process safeguards, of a municipal employee, even though a city ordinance seemingly stipulated that such a dismissal could be only for "cause." 109 The decision suggests that statutorily created property interests do not necessarily qualify for judicially imposed due process protection if the same statute also specifies, as permissible means for terminating the interest, procedures for making factual determinations. Once legislative specification of even "unfair" procedures is accepted, then legislative specification of the extreme case of inadequate procedure, the conclusive presumption, also becomes respectable. Yet Turner, Jimenez, and Lucas preclude the application of such a broad reading of Bishop to statutes involving such sensitive areas as sex classification, child-rearing and illegitimacy. ${ }^{110}$

Although Turner in particular seems to assure a continued though less expansive role for the conclusive presumption doctrine, two important questions remain, especially in the wake of Bishop. First, is it possible to formulate a viable conclusive presumption doctrine as an extension of procedural due process? Second, would such a doctrine address issues not reviewed satisfactorily under other due process and equal protection principles?

\section{Limiting Principles Inherent in Procedural Due Process Analysis}

Two principles that limit the procedural conclusive pre. sumption doctrine to manageable proportions can be distilled

${ }^{109}$ Id. at 342-45. Bishop does not rest comfortably next to Arnett v. Kennedy, 416 U.S. 134 (1974). See text accompanying notes 17-25 supra. The Court did distinguish the two cases, however. The federal statute at issue in Amett was construed to confer a protected property right in continued employment. Professing deference to local court interpretation of state and municipal law, id. at 345-47, the Bishop Court noted that since property interests are created "by existing rules or understandings that stem from an independent source such as state law," Board of Regents of State College v. Roth, 408 U.S. 564, 577 (1972), and since the local court in Bishop-actually a federal district court-found that under local law the employee "held his position at the will and pleasure of the city," id. at 345 , a protected property interest was not implicated. Id. at 347. As Justice White explained in dissent, however, the Bishop district court construed the local ordinance's employment termination provisions before Arnett's explanation of how such laws were to be evaluated for purposes of applying procedural safeguards. Id. at 355 (White, J., dissenting).

${ }^{110}$ See text accompanying notes 67-107 supra. 
from the conclusive presumption cases. The first limiting principle concerns the extent to which a legislative or administrative provision, challenged as a conclusive presumption, pursues a substantive policy objective. Conclusive presumption analysis does not address policy judgments concerning reasonable nonprocedural objectives, such as the allocation of limited resources. The second limiting principle concerns the feasibility of an individualized determination process as a reasonable alternative to a conclusive presumption. These doctrinal constraints are characteristic of procedural due process analysis and serve to balance procedural safeguards against legitimate program goals.

\section{A. The Pursuit of a Procedural Objective}

A court may hold a statutory classification to be a conclusive presumption when it construes the classification as a procedural short cut. A classification constitutes such a short cut when the government fails to provide adequate factfinding procedures for the termination, reduction, or denial of benefits for which eligibility has been defined in terms of discrete statutory or administrative criteria. In the language of current procedural due process doctrine, interests defined by such criteria are "protected property or liberty interests," 111 and the allocation of these interests brings into play the principles announced in the administrative due process cases: ${ }^{112}$ the question is whether the governmental decision at issue can be made only after an individualized determination of fact. ${ }^{113}$

Sometimes, however, a statutory provision challenged on procedural grounds is also subject to a substantive characterization. In Heiner $v$. Donnan, ${ }^{114}$ for example, the provision characterized as a conclusive presumption-a surrogate for a factfinding procedure-also can be viewed as an expression of substantive policy. ${ }^{115}$ In form, the substantive aim of the statute

\footnotetext{
${ }^{111}$ See notes 14-15 supra \& accompanying text.

112 See text accompanying notes 13-33 supra.

${ }^{113}$ See text accompanying notes 13-16 supra.

${ }_{114} 285$ U.S. 312 (1932). The case is discussed in text accompanying notes 35-39
} supra.

115 With regard to conclusive presumptions, Wigmore has stated:

In strictness, there cannot be such a thing as a "conclusive presumption."

Wherever from one fact another is said to be conclusively presumed, in the sense that the opponent is absolutely precluded from showing by any evidence that the second fact does not exist, the rule is really providing that, where the first fact is shown to exist, the second fact's existence is wholly immaterial for 
was to place a higher estate tax on gifts made in contemplation of death, while procedurally it presumed that all persons dying less than two years after making a gift made it in contemplation of death. ${ }^{116}$ One can construe this statutory scheme, however, as creating a two-part substantive category of tax liability. By ignoring the statute's form, it can be interpreted as imposing the tax on all gifts made in contemplation of death plus all gifts made within two years of death regardless of the donor's intentions. Because the Court did not ignore the form of the statute, ${ }^{117}$ however, it viewed its invalidation as the elimination of an unfair process only and not as a threat to the substantive aim of the tax statute.

A conclusive presumption doctrine that derives from principles of procedural due process must be sensitive to the degree to which a statute pursues legitimate substantive goals. An analysis of the Supreme Court's conclusive presumption rulings provides an opportunity for assaying whether the doctrine can be responsive to varying procedural and substantive factors.

\section{Laws Pursuing Only Procedural Short Cuts}

\section{a. Legislation}

The procedural due process justification for the conclusive presumption doctrine is clearest where statutory construction reveals that the provision in question was designed to serve a procedural purpose only. Thus, in United States Department of Agriculture v. Murry, ${ }^{118}$ the Court surveyed the legislative record of section 5(b) of the Food Stamp Act ${ }^{119}$ and concluded that its substantive goal was curbing "abuses of the program by 'college students, children of wealthy parents." "120 The Court found that the section's denial of food stamp eligibility to all households containing persons 18 years or older claimed as dependents by taxpayers who are themselves ineligible for food stamps, regard-

the purposes of the proponent's case; and to provide this is to make a rule of substantive law, and not a rule apportioning the burden of persuading as to certain propositions or varying the duty of coming forward with evidence.

$9 \mathrm{~J}$. WigMore, Evidence $\S 2492$ (3d ed. 1940).

116 See 285 U.S. at 320.

117 See id. at 328-29.

118413 U.S. 508 (1973). The case is discussed in text accompanying notes $49-51$ supra.

1197 U.S.C. $\S 2014$ (b) (1970).

120413 U.S. at 513 (quoting 116 Cong. Rec. 41979 (1970) (remarks of Rep. Latta). 
less of whether the dependents received sufficient outside income to escape indigency, represented an effort to avoid individualized determinations of whether tax dependents did in fact receive substantial amounts of outside income from their wellheeled parents ${ }^{121}$ - that is, a procedural short cut. Consequently, invalidating section 5(b) did not preclude Congress from attaining the same substantive objective by legislation that provides for individualized determinations. Such a judicial directive to pursue a procedural end by fair procedural means is consonant with the fair adjudication theme developed in the procedural due process rulings. ${ }^{122}$

Bell v. Burson ${ }^{123}$ also invalidated a provision comfortably construed as serving only a procedural purpose. The Georgia legislation contested there was designed to ensure that possible tortfeasors show, either through accident insurance or by posting security, that they could provide compensation for damage they caused. This substantive objective only required that uninsured motorists post security when there was a reasonable possiblity that they would be found liable for damages in the amount claimed. Consequently, the Bell requirement that Georgia make a determination that there is a reasonable possibility that an uninsured motorist will be found liable before depriving him of his license only serves to confine the statute's procedural scope to its substantive objective.

The death benefits legislation in Weinberger $v$. Salfi ${ }^{124}$ also falls into this category. The legislative history and the primary defense asserted by HEW described the duration-of-relation requirement as safeguarding the Social Security insurance program from marriages designed solely to create insurance beneficiaries. ${ }^{125}$ Salfi's distinction is that the Court conceded the procedural short cut objective of the nine-month requirement-and then proceeded to justify it. Under a permissive re-

\footnotetext{
${ }^{121}$ See id. at 513-14.

${ }^{122}$ See text accompanying notes 13-33 supra. For an alternative interpretation of Murry, see Tribe, supra note 4 , at 49 n.224.

${ }_{123} 402$ U.S. 535 (1971). The case is discussed in text accompanying notes $40-45$ supra.

124422 U.S. 749 (1975). The case is discussed in text accompanying notes 55-66, supra.

${ }^{125}$ See id. at 776-85. A second defense-that the requirement served the objective of aiding only those persons who were likely to have become dependent on the income of the deceased wage earner-is also subject to a procedure avoidance characterization. In any case, it was only half-heartedly presented, and the Court gave it only passing attention. See id. at 776 n.11.
} 
view standard, Justice Rehnquist concluded that Congress rationally could decide to eschew individualized determinations and use the presumptive approach to assure proper risk management for the insurance program. ${ }^{126} \mathrm{He}$ also supported the presumptive standard as a means for avoiding costly administrative procedures and delays. ${ }^{127}$

Such programmatic concerns are not alien to procedural due process analysis. As explained above, ${ }^{128}$ the Court has fashioned a balancing test for evaluating the impact of prcedural requirements on the realization of governmental program goals. Under that test, accommodation is possible between procedural safeguards and program needs. Vlandis $v$. Kline ${ }^{129}$ and Mourning v. Family Publications Service, Inc. ${ }^{130}$ discussed below, ${ }^{131}$ demonstrate how the Court has recognized the need to address conclusive presumptions in a manner that is compatible with valid program goals. Salfi, however, does not represent such a reasonable balancing exercise.

\section{b. Administrative Rules}

When an administrative rule is challenged as creating a conclusive presumption, a reviewing court can effectively probe administrative action to uncover a procedure-avoidance objective. Administrative rulings often are subject to the clarifying testimony of those primarily responsible for the regulation in question. ${ }^{132}$ For example, in the early 1970's the Department of Housing and Urban Development became concerned about rising tenant default rates in rental projects receiving federal interest subsidies and mortgage insurance. ${ }^{133}$ On June 13, 1972, HUD issued a policy notice, which it conceded was designed to screen out tenants considered likely to default, ${ }^{134}$ that rendered any household that would have to devote more than thirty-five per cent of its adjusted income for rent ineligible for admission to specified housing. In Mandina $v . L y n n,{ }^{135}$ a federal district

${ }^{126}$ See id. at 776,780 .

${ }^{127}$ See id. at 781-85.

${ }^{128}$ See text accompanying notes 26-33 supra.

${ }^{129} 412$ U.S. 441 (1973). The case is discussed in text accompanying note 48 supra.

130411 U.S. 356 (1973).

${ }^{231}$ See text accompanying notes 204-13 infra.

${ }^{132}$ See, e.g., Findrilakis v. Secretary of Dep't of Housing \& Urban Dev., 357 F. Supp. 547, 550 (N.D. Cal. 1973).

${ }^{133}$ See id.

${ }^{134}$ See 37 Fed. Reg. 11758 (1972).

135357 F. Supp. 269 (W.D. Mo. 1973). 
court invalidated the HUD policy notice as creating an illegal conclusive presumption. Mandina required HUD to afford an applicant the opportunity to reverse the established presumption-such as by showing a history of reliable rent payment at a rent-income ratio above the thirty-five percent criterion. ${ }^{136}$

\section{Spurious Claims of Substantive Objectives}

Although courts are accustomed to determining statutory purpose in order to decide how a statute should operate, ${ }^{137}$ when challengers of a statute claim that its objectives should be examined to ascertain whether the underlying goal is impermissible, courts frequently have declined to investigate on the traditional ground that judicial inquiry into legislative "motive" is improper. ${ }^{138}$ Nevertheless, when the Supreme Court has determined that a challenged provision was designed to serve an unfair procedural purpose, judicial restraint has not stopped it from invalidating the provision as an impermissible conclusive presumption. ${ }^{139}$ This form of judicial reversal is apparently more acceptable to the Court than other "impermissible purpose" invalidations, because a legislature can enact procedurally adequate legislation that still will achieve its substantive objective. ${ }^{140}$

Reviewing courts, however, may be offered substantive objectives, invented to short-circuit procedural challenges, for provisions that appear to pursue procedural goals. Identification of a procedural purpose has been relatively easy in most of the recent conclusive presumption cases. The Stanley, LaFleur, Salfi, and Turner defendants volunteered procedural defenses, among

${ }^{136} I d$. at 278-79. In addition, the Mandina court found that, using a correct formulation of the basic rental costs under the statute, "the plaintiff clearly is able to pay the basic rent with not more than thirty-five percent of his adjusted income as required by this Circular and thus he qualifies for membership in ... the housing in question." 357 F. Supp. at 276. As an alternative ground of invalidation, the court held that the issuance of the policy notice violated the procedural requirements for the publication of department rules and regulations contained in 24 C.F.R. $\$ 10.5$ (1976).

${ }^{137}$ See Ely, Legislative and Administrative Motivation in Constitutional Law, 79 YALE L.J. 1205, 1212-14 (1970). See generally A. Bickel, The Least Dangerous Branch (1962).

${ }^{138}$ See, e.g., Palmer v. Thompson, 403 U.S. 217 (1971); Ely, supra note 137.

${ }^{139}$ See text accompanying notes 111-31 supra and 144-68 infra.

${ }^{140}$ Recently, in cases involving laws phrased in racially neutral terms, the Supreme Court has stated that courts hearing racial discrimination challenges to laws neutral on their face should determine whether these laws serve a hidden purpose to disadvantage a racial minority. See, e.g., Arlington Heights v. Metropolitan Housing Corp., 97 S. Ct. 555 (1977); Washington v. Davis, 426 U.S. 229 (1976). 
others. ${ }^{141}$ The statute at issue in Vlandis, in light of Justice Stewart's characterization of residency as equivalent to domicile, ${ }^{142}$ carried a procedural purpose on its face, and the procedural interpretation of the statute in Murry was not countered by a substantive explanation from the Agriculture Department. ${ }^{143}$ Turner, however, does provide an example of an effort to disguise a procedure-avoidance provision.

Arguing before the Utah Supreme Court, the agency defendant in Turner characterized its eighteen-week exclusion of pregnant women from unemployment compensation as resting on the premise that "near term pregnancy is an endemic condition relating to employability."144 This statutory interpretation was adopted in the opinion issued by the Utah court. ${ }^{145}$ Neither the Utah agency nor the court considered more individualized determinations of employability to be necessary. Before the United States Supreme Court, however, the agency argued that the provision was designed to limit coverage of the Utah unemployment compensation system, not to create a presumption concerning employability. ${ }^{146}$ This switch aroused the Court's skepticism, and, pointing to the procedural construction of the statute by Utah's highest court, it refused to analyze the statute in terms of the proffered substantive rationale. ${ }^{147}$

It is appropriate for the courts to invalidate statutory provisions challenged as conclusive presumptions when such provisions are defended with questionable or seemingly contrived substantive explanations of their objectives. Upon invalidation, a legislature would have the option of reenacting the suspect provision, clarified by an explicit statement of substantive purpose. This remand-type process would serve the salutory function of enabling aggrieved parties and the courts to assess the legitimacy of the clarified policy objective. In fact, in at least two of the

141 In Stanley, the Court considered Illinois' conclusive presumption practice to serve administrative convenience. See 405 U.S. at 654-58. The procedural objective expressed in LaFleur was identification of teachers physically incapable of teaching. See 414 U.S. at 640-41, 643-47. For descriptions of the procedural defenses in Salfi and Turner, see text accompanying notes 124-27 supra and 144-47 infra.

${ }^{142}$ See 412 U.S. at 442-43, 448-52.

${ }^{143}$ See 413 U.S. at 512-14. But see id. at 524 (Rehnquist, J., dissenting).

${ }^{144} 423$ U.S. at 45 n.*.

${ }^{145} I d$.

${ }^{146}$ Id.

${ }^{147}$ See id. The Court did not state whether it would have looked behind a seemingly contrived substantive rationale for the statute had the rationale been offered by the legislature. 
conclusive presumption cases already decided by the Supreme Court, the defendants did not present available substantive arguments, possibly because those arguments involved statutory objectives considered vulnerable to invalidation. ${ }^{148}$ Also, because a conclusive presumption invalidation of a statutory provision does not preclude achievement of substantive policy objectives of the legislation, it is unlikely that a legislature would reenact an unfair procedure accompanied by a statement of a contrived substantive purpose. ${ }^{149}$

\section{Provisions Pursuing Procedural Objectives and Also Raising Substantive Questions}

Stanley $v$. Illinois ${ }^{\mathbf{1 5 0}}$ and Cleveland Board of Education v. LaFleur ${ }^{151}$ involved measures ostensibly pursuing procedural objectives. The presumption of paternal unfitness in Stanley and the mandatory leave requirements in LaFleur, however, also could be characterized either as the pursuit of illegitimate substantive objectives or as the pursuit of legitimate substantive objectives in a substantively unacceptable manner. These invalidation rulings, therefore, are vulnerable to contentions that the procedural appearance of the opinions is only a disguise for substantive evaluations. ${ }^{152}$ Moreover, since the conclusive presumption language employed in these cases mirrors the doctrinal statements made in cases like Murry, where only procedural questions were argued, ${ }^{153}$ these cases give rise to a temptation to question the integrity of the conclusive presumption doctrine as a whole. ${ }^{154}$

In Stanley, Justice White, speaking for the majority, was able to analyze the case on procedural terms without difficulty because the state defended the challenged provision as solely a

${ }^{148}$ See text accompanying notes 155-56, 161 infra.

${ }^{149}$ Cases involving conclusive presumption invalidation are unlike other cases that might generate political pressure for reenactment of a provision invalidated for reasons of illegitimate purpose, such as those involving charges of discriminatory intent. The latter cases also would invite more respectable alternative purpose statements. For example, a municipality that takes the possibly popular action of closing all of its swimming pools-apparently to frustrate a desegregation order-can advance the nonracial explanation that fiscal considerations motivated the action. See Palmer v. Thompson, 403 U.S. 217 (1971). Thus, conclusive presumption invalidations by the judiciary generally should not suffer from legislative evasion because legislators are unlikely to articulate false policy goals that might have little appeal to their constituents.

${ }^{150} 405$ U.S. 645 (1972).

151414 U.S. 632 (1974).

${ }^{152}$ See text accompanying notes $155-66$ infra.

${ }^{153}$ See text accompanying notes $118-22$ supra.

${ }^{154}$ See generally text accompanying notes 53-66 supra. 
procedural device. ${ }^{155}$ A possible substantive objective for the law, punishment of unwed fathers and deterrence of fathering illegitimate children, was not raised. Stanley indicated that when confronted with legislation vulnerable to a procedural challenge, the Court would not probe for alternative substantive explanations not explicitly introduced in the statute's defense. ${ }^{156}$ Of course, the legislature retains the option to enact legislation containing language highlighting the substantive objective that was ignored in the judicial review of the conclusive presumption. If a procedure-avoidance objective still could be discerned, a court reviewing the new legislation then would have a clear obligation to fashion a procedural ruling that would accommodate the substantive objective-assuming the court finds that objective legitimate. ${ }^{157}$

LaFleur is more difficult to defend as a procedural ruling. Two public policy aims of the mandatory maternity leave provision were offered in its defense-assuring instructional continuity ${ }^{158}$ and keeping physically unfit teachers out of the classroom, for both educational and safety reasons. ${ }^{159}$ The latter objective presented the procedural issue: ${ }^{160}$ What procedural mechanism may the state permissibly use to identify those teachers who are, because of pregnancy, physically unfit to teach? A third substantive objective-keeping visibly pregnant teachers out of the classroom-was not raised, apparently because the school board doubted its legitimacy. ${ }^{161}$

Regarding the first defense, Justice Stewart, speaking for the majority, concluded that the rules prescribing mandatory leave at the end of the fourth or fifth month of pregnancy bore "no rational relationship to the valid state interest of preserving

${ }^{155}$ See 405 U.S. at 647-50.

${ }^{156}$ Subsequently, when the Court reversed itself on the issue of conclusive presumptions in Salfi, it rejected a challenge to a statutory provision characterized primarily as serving a procedural objective. The search for substantive characterizations for the statute was minimal in Salfi because, discarding a conclusive presumption doctrine derived exclusively from procedural due process principles, the Court decided the case on minimum rationality grounds. See 422 U.S. at 772.

${ }^{157}$ For an example of this type of review and accommodation, see text accompanying notes $169-87$ infra.

158414 U.S. at 640 .

${ }^{159} I d$. at 641 .

${ }^{160}$ See id. at 643-47.

${ }^{161} I d$. at 641 n.9. In his concurring opinion, Justice Powell asserted that, in fact, the objective of keeping "visibly pregnant teachers out of the sight of school children" was "a principal purpose behind the adoption of the regulations." Id. at 653 (Powell, J., concurring). 
continuity of instruction."162 As an example of the rules' irrationality, he pointed out that such rules might compel some perfectly fit teachers to leave school before completing the school year, thereby impeding instructional continuity. ${ }^{163}$ The argument can be made, however, that long lead times and easily identifiable departure dates are necessary to assure minimal teacher turnover because they enable a school system to hire substitute teachers able to serve for a lengthy period. Moreover, just as the practice of last minute departures allows some pregnant teachers to complete an academic year, it also permits others to start an academic year even if they can continue for only a few weeks. Consequently, in terms of minimal rationality, ${ }^{164}$ one can question the ease with which Justice Stewart disregarded the rules as a means of protecting continuity of instruction. Justice Stewart, therefore, really seems to have been saying that the mandatory leave rules were unreasonable relative to their negative effect on the important and protected "freedom of personal choice in matters of marriage and family life."165

Once the maternity leave provision was rejected as an illegitimate means of achieving instructional continuity, only the objective of assuring teacher fitness remained before the Court. The teacher fitness question, on its own, presented the procedural issue of fair determination of fact that Justice Stewart could-and apparently did-evaluate in terms of procedural due process principles. ${ }^{166}$ The Court's approach to the continuity goal-requiring a greater-than-minimal justification for the provision because of the strong liberty interest involved ${ }^{167}$-raises questions, however, about whether a substantive judgment predetermined the outcome of the procedural analysis. It is at least

${ }^{16^{2}} \mathrm{Id}$, at 643

${ }^{163} \mathrm{Id}$.

${ }^{164}$ For a discussion of the minimum rationality test, see Note, Legislative Purpose, Rationality, and Equal Protection, 82 YALE L.J. 123 (1972). Indeed, this Note argues that under a multiple legislative purpose analysis any statute survives a minimum rationality review. Although LaFleur does not require a compelling interest justification for the maternity rules, it does appear to place a higher burden of justification on the school board rules, at least insofar as they were designed to assure continuity of instruction, because they burdened "one of the basic civil rights of man," 414 U.S. at 640, enjoying some degree of special constitutional protection. See text accompanying notes 71-82 supra. The subsequent Turner analysis adds to the suspicion that a substantive, special interest analysis influenced the procedural review in LaFleur. See text accompanying notes $67-70,83-84$ supra.

165414 U.S. at 639 .

${ }^{166} \mathrm{Id}$. at 643-50.

${ }^{167}$ See id. at 639-40. 
possible that the LaFleur majority may have placed a heavier burden of justification on the procedural mechanism, regardless of any other concerns it nurtured about the fairness of the procedure. ${ }^{168}$ Once judicial review is reduced to an assessment of a procedural provision, however, the conclusive presumption test for procedural fairness is appropriate regardless of whether a new reasonableness review could also be applied.

\section{Provisions Pursuing both Legitimate Substantive Goals and Procedural Short Cuts}

Some laws can be construed as serving a legitimate substantive goal as well as a procedural purpose. In reviewing such laws, the courts are not likely to apply the conclusive presumption doctrine in a manner that will preclude the attainment of legitimate substantive objectives. For example, although minimum age limitations for access to driving licenses and alcoholic beverages might be assailed as impermissible surrogates for individualized determinations of competence and maturity, ${ }^{\mathbf{1 6 9}}$ the spectacle of precocious sixth graders drinking beer and cruising around town contravenes prevailing theories of proper child rearing, elementary education, and ascent to adulthood. Regardless of how well some sixth graders could hold their beer or control their cars, a legislature can justify the age minimums as measures designed to prevent such forms of behavior from engendering socially undesired attitudes on the part of the precocious children and from exerting an unwanted influence on their more ordinary comrades.

When a statutory provision expressly announces a procedural objective, however, even if it also serves a legitimate substantive goal, a court may feel impelled to conduct a conclusive presumption review to assure procedural fairness. Thus, in Vlandis $\%$. Kline ${ }^{\mathbf{1 7 0}}$ the Court found an explicit effort to avoid procedural determinations by conclusively presuming certain facts. ${ }^{171} \mathrm{~A}$ Connecticut law classified an applicant to a Connecticut public college as an "out-of-state" student throughout the student's entire stay at the college if the student was unmarried

${ }^{168}$ See id. at 647-48. Indeed, in Turner the Court clearly combined a substantive concern for the special interest in childbearing with procedural fairness principles to invalidate a conclusive presumption. See text accompanying notes 67-70, 83-84 supra.

${ }^{169}$ See, e.g., id. at 658-59 (Rehnquist, J., dissenting).

170412 U.S. 441 (1973).

${ }^{171}$ Id. at 451. 
and his "legal address for any part of the one-year period immediately prior to his application for admission ... was outside of Connecticut"; ${ }^{172}$ a married student who lived with his spouse and had a "legal address at the time of his application ... outside of Connecticut"173 was similarly classified. According to Justice Stewart, who wrote the majority opinion, these residency provisions served as substitutes for individual determinations of a generally recognized residency status, essentially akin to domicile. ${ }^{174}$ Consequently, the Court ordered a more individualized residency determination. ${ }^{175}$

The Supreme Court recognized, however, that the provisions challenged in Vlandis also served a legitimate state policy-the subsidization of Connecticut residents attending Connecticut's state colleges ${ }^{176}$ — which would be jeopardized by the requirement of individualized determinations of residency. In this sense, because many out-of-state applicants could "arrange" to satisfy the usual indicia of domicile, the Connecticut legislature was not attempting to avoid the procedural burden of adjudicatory factfinding, but rather the very result of factfinding. If Connecticut were forced to charge lower tuition and fees to many out-of-state students, it might decide to reduce the subsidy provided to all students qualifying as Connecticut residents. ${ }^{177}$ To the extent permitted by law, it also might impose stringent restrictions on the admission of out-of-state students. Possibly, the state would cut back on some of its college programs to compensate for money lost because of a decline in tuition revenue from out-of-state students. ${ }^{178}$ These possibilities demonstrate the potentially highly disruptive effect of the Court's order that Connecticut ascertain residency on an individual basis.

Vlandis represents a concession to the substantive policy in-

172 Id. at 442 (quoting ConN. GeN. STAt. Rev. $\$ 10-329$ (b) (Supp. 1969), as amended by Pub. Act. No. 5, \& 122 (June 1971)).

${ }^{173}$ Id. at 443 (quoting Conn. GeN. Stat. Rev. $\$ 10-329$ (b) (Supp. 1969), as amended by Pub. Act. No. 5, § 126(a)(3) (June 1971)).

${ }^{174} I d$. at $448,453-54$.

175 See id. at 453-54.

${ }^{176}$ See id. at $452-53$.

${ }^{177}$ See Weisbrod, Geographic Spillover Effects and the Allocation of Resources to Education, in The Public Economy of Urban Communities 192 (J. Margolis ed. 1965). Weisbrod concludes that benefit spillovers, viewed in terms of the migration of graduates out of a local public school system, lead to a reduction in local education expenditures. Id. at 204-05.

${ }^{178}$ See 412 U.S. at 464-65 (Rehnquist, J., dissenting). 
terest threatened by the anti-conclusive presumption holding. The majority, although striking down the Connecticut residency definitions, cited with approval an earlier summary affirmance of a lower court decision approving Minnesota's requirement that a student reside in the state for one year in order to qualify for a reduced tuition rate. ${ }^{179}$ Since the Minnesota regulation allows a student to offer proof of domicile after living in the state for one year-the one year's residence serves as one indicator of domicile-an out-of-state student can take advantage of the lower tuition and fees starting with his or her second year of state college enrollment. ${ }^{180}$ Nevertheless, Minnesota does establish the conclusive presumption that no state college applicant who has resided in Minnesota for less than one year is a state resident at the time of matriculation or at any time during the first school year. ${ }^{181}$ The only difference between the Minnesota presumption that was upheld and the Connecticut presumption that was stricken is the permanence of Connecticut's conclusive presumption. The Court's acceptance of the Minnesota scheme allows the state to have a workable policy of subsidizing in-state public college students. A state college system like Minnesota's is assured of at least one year's higher tuition and fees from outof-state students; even this limited preservation of the differential tuition and fee system provides financial support for maintaining lower cost education for longtime state residents.

Similarly, in LaFleur, Justice Stewart may have been suggesting an analogous accommodation of procedural fairness and policy objectives-in that case the objective of assuring continuity of instruction. Although he rejected the lengthy enforced maternity leave implemented by the school boards, Justice Stewart did suggest that insofar as " $t]$ he Fourteenth Amendment requires the school boards to employ alternative administrative means, which do not so broadly infringe upon basic constitutional liberty, in support of their legitimate goals," 182 rules "requiring a termination of employment at some firm date during the last few weeks of pregnancy"183 might be acceptable. Such later dates, representing a reasonable accommodation of competing interests,

${ }^{179} 412$ U.S. at $452-53$ n.9, (citing Starns v. Malkerson, 326 F. Supp. 234 (D. Minn. 1970), aff'd mem., 401 U.S. 985 (1971)).

180412 U.S. at $452-53$ n.9.

${ }^{181}$ See id. at 467 (Rehnquist, J., dissenting).

182414 U.S. at 647.

${ }^{183} \mathrm{Id}$. at 647 n.13. 
would constitute a conclusive presumption similar to the oneyear residency requirement accepted in Vlandis. ${ }^{184}$

The Vlandis accommodation of procedural protection and achievement of substantive policy goals reflects the balancing formula developed in Goldberg $v$. Kelly ${ }^{185}$ and subsequent procedural due process cases. ${ }^{186}$ Because the conclusive presumption doctrine is designed to guarantee appropriate procedural safeguards, the doctrine is not any more protective of procedure at the expense of program objectives than is the parent doctrine of procedural due process. Just as cases like Arnett $v$. Kennedy ${ }^{187}$ limited procedural protections to permit fair realization of legislatively prescribed policy objectives, Vlandis also stopped short of an absolute bar to a conclusive presumption in order to protect a legitimate program goal.

\section{B. The Reasonableness of Individualized Determinations as an Alternative to a Presumption}

Application of conclusive presumption analysis, limited by the requirement that the provision under review can be characterized as having a procedural purpose, ${ }^{188}$ is also constrained by the feasibility of individualized factfinding as an alternative to a conclusive presumption. The Supreme Court often has asserted that due process interests supersede claims of mere administrative convenience. ${ }^{189}$ Convenience, however, is not the same as feasibility; thus, for example, in Vlandis and LaFleur the Court expressly observed that "reasonable alternative means" for achieving a procedural objective were available. ${ }^{190}$

${ }^{184}$ This analysis puts LaFleur in the same category as Vlandis; that is, cases involving both a clear and legitimate substantive objective as well as a procedure-avoidance device. In the preceding section, text accompanying notes 150-68, supra, LaFleur could be analyzed as a case reducible to a procedural question alone because the Court invalidated, by employing a sliding scale equal protection analysis, the rules implemented by the school boards as a means for achieving instructional continuity. The inquiry then focused on the rules as a mechanism for determining the physical capabilities of pregnant teachers. See text accompanying notes 158-68, supra. Once the Court's focus returns to a legitimate substantive objective in LaFleur-the promotion of instructional continuity-the fashioning of a remedy for procedural unfairness should attempt to accommodate, to some degree, achievement of that legitimate objective.

185397 U.S. 254 (1970).

${ }^{186}$ See text accompanying notes 13-33 supra.

187416 U.S. 134 (1974).

${ }^{188} \mathrm{See}$ text accompanying notes $111-87$ supra.

189 See, e.g., Stanley v. Illinois, 405 U.S. 645, 656-58 (1972).

${ }^{190}$ Cleveland Bd. of Educ. v. LaFleur, 414 U.S. 632, 647 n.14 (1974); Vlandis v. Kline, 412 U.S. 441, 454 (1973). 


\section{The Presence of Recognizable Standards}

A primary factor affecting procedural feasibility is the substantive nature of the statute in question. As Justice Brennan observed in his Salfi dissent, the Court has struck down conclusive presumptions only where it was "possible to specify those factors which, if proven in a hearing, would disprove a rebuttable presumption." invalidated conclusive presumptions, the statute or regulation in question contained an express or implicit standard, recognized and understood by the affected parties, that could be applied on an individualized basis to determine the existence or nonexistence of the same facts that the provision instead presumed. In Murry, for example, the predominant redistributive goal of the Food Stamp Act was to aid households defined as needy in terms of per capita income; the Court rejected section 5(b) of the Act because it conclusively presumed that certain households did not satisfy that objective income standard. ${ }^{192}$ Similarly, no one really contended that the physical fitness of pregnant teachers in $L a$ Fleur or the capacity of a pregnant clerk to continue working in Turner could not be determined on an individual basis by applying commonly accepted medical standards. ${ }^{193}$ The parental unfitness presumed in Stanley could be determined on an individual basis by applying commonly accepted legal standards of "reasonable fitness." ${ }^{194}$ Bell required only a simple preliminary determination of liability in an automobile accident, ${ }^{195}$ and even the residency question in Vlandis was answerable in terms of existing criteria for a determination of domicile. ${ }^{196}$ Moreover, as Justice Brennan explained, evidence of a wage earner's good health at the time of marriage could disprove the insurance collusion feared in Salfi. ${ }^{197}$

If a challenged statute or regulation does not contain some indication of the facts that could be determined in an indi-

191422 U.S. at 804 (Brennan, J., dissenting).

${ }^{192}$ See text accompanying notes 118-22 supra.

${ }^{193}$ See 414 U.S. at 645 n.12, 647 n. 14.

194 When an unwed father is not involved, Illinois provides for determination of parental fitness in a neglect proceeding. ILl. ANN. STAT. ch 37, § 704-8 (Smith-Hurd 1972), Juvenile Court Act $\S 4-8$ (providing that the "best interests of the minor and the public" are to be considered in deciding whether a child is to be made a ward of the court due to delinquency or neglect).

195402 U.S. at $539-43$.

196412 U.S. at 454.

197422 U.S. at 804 (Brennan, J., dissenting). 
vidualized proceeding, then a conclusive presumption invalidation would require a legislature not only to create an indivdualized procedure, but also to make substantive judgments concerning the goals of the procedural determination. Conclusive presumption invalidations necessitating such legislative judgments would intrude the courts much more deeply into the legislative process than is the case under present due process and equal protection law. Statutory reliance on income limits for apportioning social welfare subsidies, for example, can be viewed as a procedural short cut for making individualized determinations of "need" and so might appear vulnerable to a conclusive presumption invalidation: individuals are precluded from demonstrating "need" if their incomes are above the prescribed level. A relatively objective alternative, however, is not discernible from the program goal of a social welfare statute. Although households above a specified income limit may be needier than or equal in need to households below the limit, demarcation of poverty levels to determine true "need" involves difficult line drawing questions not present in the conclusive presumption cases already decided. Although need standards could be developed that take into account relevant factors in addition to per capita income, formulating these standards necessarily would embroil the judiciary in policy considerations. Must a need test allow households to deduct all medical expenditures? Should medical deductions be permitted only after discounting the cost of medical services to the lowest cost services available in each household's community? Can ordinary illnesses be excluded from the deduction category because such illnesses average out over time for households above and below the subsidy eligibility line as presently drawn? Similar questions can also be raised concerning the manner in which a multitude of other factors should affect eligibility for social welfare programs.

The conclusive presumption decisions have accepted legislative standards as given. ${ }^{198}$ They do not require law makers to establish categories precisely tailored to fit the overall goals of a statute. A requirement of categorical exactness would require legislatures to expend much of their energy making adjudicatory-type decisions. Generally, constitutional principles require

${ }^{198}$ See text accompanying notes $191-97$ supra and note 200 infra \& accompanying text. 
only that legislative standards create resonably inclusive categories, thereby allowing lawmakers the latitude necessary for framing laws of general application; ${ }^{199}$ a law designed to fight a certain problem need not attack all causes of the problem. ${ }^{200}$ To guarantee that legislatures do not choose unfair procedures for applying the standards that implement the statute's policy goals, however, the courts properly have invoked the conclusive presumption doctrine.

\section{A Balancing Analysis of the Administrative Burden}

The Court's concern for the availability of a reasonable alternative procedure to a conclusive presumption in LaFleur and Vlandis ${ }^{201}$ indicates that the Court is reluctant to require extraordinarily costly individualized determinations. The Court's acceptance of what amounts to a one-year conclusive presumption in the state college residency cases, for example, may, in part, signal a sensitivity to the weight of the administrative burden that results from an individualized determination of residency. Indeed, in Vlandis Justice Stewart expressed an awareness "of the special problems involved in determining the bona fide residence of college students who come from out of State to attend that State's public university." ${ }^{202}$ He then asserted that a reasonable durational residency requirement can legitimately serve "as one element in demonstrating bona fide residence."203

The Supreme Court also has indicated that an individualized determination is unnecessary when no one is significantly harmed by the use of a conclusive presumption and when the use of an individualized process would substantially undermine the effectiveness of a regulatory law. Regulation $\mathrm{Z}^{204}$ promulgated by the Federal Reserve Board in implementation of the 1968 Truth in Lending Act, ${ }^{205}$ directs businesses that extend credit payable in more than four installments to make disclo-

199 See, e.g., sources cited in note 3 supra.

200" Firmly established equal protection doctrine recognizes that "reform may take one step at a time, addressing itself to the phase of the problem which seems most acute to the legislative mind." Williamson v. Lee Optical Inc., 348 U.S. 483, 489 (1955).

201 See text accompanying notes 170-87 supra.

2112412 U.S. at 452 . For a discussion of the weight to be given financial considerations in determining whether due process requires a particular procedural safeguard, see Mathews v. Eldridge, 424 U.S. 319, 347-48 (1976).

203412 U.S. at 452.

${ }^{204} 12$ C.F.R. $\$ \$ 226.1-.12$ (1976).

${ }^{2 n 5} 15$ U.S.C. $\S \S 1601-1665$ (1970 \& West Supp. 2, 1976). 
sures mandated by the Act. ${ }^{206}$ The Act itself only required merchants to make these disclosures if they "extend credit, with attendant finance charges."207 In Mourning v. Family Publications Service, Inc. ${ }^{208}$ a magazine subscription company claimed that since the statutory disclosure requirements only apply when a merchant has attached a finance charge to extended credit, Regulation $\mathrm{Z}$ conclusively presumes that all extensions of credit repayable in more than four installments include finance charges. ${ }^{209}$ Although the Mourning majority professed not to see the alleged presumption, ${ }^{210}$ the Court's approval of Regulation $\mathrm{Z}$ could be justified under the theory that the disclosure requirement's broad classificatory trigger is necessary for the effective operation of the statute. ${ }^{211}$ Moreover, the Court in Mourning could have considered the harm to the affected parties to be relatively insignificant.

Judicial acceptance of presumptive determinations in the Mourning context reflects the balancing approach of Goldberg $v$. $K e l l y^{212}$ and subsequent cases. The procedural due process cases exhibit a judicial refusal to impose severe administrative costs when individual harm is slight and administrative burdens would seriously weaken the efficacy of a government program. ${ }^{213}$ Similar balancing judgments appropriately can be applied in all conclusive presumption cases.

\section{Permissible Procedural Presumptions}

Even when individualized determinations are constitution-

${ }^{206} 12$ C.F.R. § 226.2(s) (1976).

${ }^{207}$ Mourning v. Family Publications Serv., Inc., 411 U.S. 356, 361 (1973) (summarizing $\S 103(f)$ of the Truth in Lending Act, 15 U.S.C. $\S 1602(f)(1970)$ ).

208411 U.S. 356 (1973).

${ }^{2119}$ See id. at 376-77 (rejecting the conclusive presumption claim on the ground that the disclosure requirement is a "prophylactic measure" rather than a conclusive presumption); $c f$. United States Dep't of Agriculture v. Moreno, 413 U.S. 528, 546-47 (1973) (Rehnquist, J., dissenting) (citing the rule at issue in Mourning as discouraging evasion of the disclosure mechanism); United States Dep't of Agriculture v. Murry, 413 U.S. 508, 522-27 (1973) (Rehnquist, J., dissenting) (arguing that conclusive presumptions are appropriate as prophylactic limitations on dispensing funds, when designed to avoid abuse through evasion or fraud).

21" See 411 U.S. at 377.

${ }^{211}$ See id. The balancing of individual interests against effective administration of a regulatory statute as a basis for upholding a conclusive presumption may quiet one critic's concern about the possible use of the conclusive presumption doctrine to invalidate regulatory statutes, in particular $\$ 16(b)$ of the Securities Exchange Act of 1934, 15 U.S.C. $\S 78(\mathrm{p})(\mathrm{b})(1970)$, dealing with insider trading. See Note, The Conclusive Presumption Doctrine: Equal Process or Due Protection?, 72 Mrch. L. Rev. 800, 833-34 (1974).

212397 U.S. 254 (1970).

${ }^{213}$ See text accompanying notes 26-33 supra. 
ally required, a governmental entity still may manage its administrative tasks by resorting to certain permissible presumptions. A rebuttable presumption, for example, may be legitimate if it is reasonable. ${ }^{214}$

In cases of rebuttable presumptions involving a broad or otherwise questionable exercise of administrative discretion, a court should require an agency to establish a factual record that supports the contention that the presumption reasonably promotes the agency's statutory mission. ${ }^{215}$ In addition, any agency must administer fairly a rebuttable presumption. If an agency disregards the favorable implications of virtually all evidence proferred by a person seeking to avoid a negative presumption, then the agency in effect is administering a conclusive presumption. To avoid this kind of abuse, an agency should specify the kind of favorable evidence that would rebut a presumption. ${ }^{216}$ Finally, under general principles of due process the courts still could review the legitimacy of a reversal burden in terms of the objectives of the statute in question.

As the Supreme Court demonstrated in Mathews v. Lucas, ${ }^{217}$ "inclusive" conclusive presumptions may also be legal. This type of presumption may be characterized as a legislative attempt to allocate a benefit by resorting to a less costly system that allows all those entitled to the benefit to receive it, while avoiding the time and expense of making individual determinations for everyone. For example, the statute involved in Lucas gave surviving child's benefits to the dependent children of deceased wage earners. The conclusive presumption upheld by the court ex-

${ }^{214}$ See, e.g., Vlandis v. Kline, 412 U.S. 441, $452-53$ n.9 (1973).

${ }^{215}$ See generally Citizens to Preserve Overton Park, Inc. v. Volpe, 401 U.S. 402 (1971); Shannon v. Department of Housing and Urban Dev., 436 F.2d 809 (3d Cir. 1970); Scenic Hudson Preservation Conf. v. FPC, 354 F.2d 608 (2d Cir. 1965), cert. denied sub nom. Consolidated Edison Co. v. Scenic Hudson Preservation Conf., 384 U.S. 941 (1966); La Raza Unida v. Volpe, 337 F. Supp. 221 (N.D. Cal. 1971), aff'd, 488 F.2d 559 (9th Cir. 1973), cert. denied sub nom. California Highway Comm'n v. La Raza Unida, 409 U.S. 890 (1972); Western Addition Community Org. v. Weaver, 294 F. Supp. 433 (N.D. Cal. 1968), vacated sub nom. Western Addition Community Org. v. Romney, 320 F. Supp. 308 (N.D. Cal. 1969); Powelton Civic Homeowners Ass'n v. Department of Housing and Urban Dev., 284 F. Supp. 809 (E.D. Pa. 1968).

216 For a discussion of such a proposal for regulatory agencies using the statistical technique of multiple regression analysis, see Finkelstein, Regression Models in Administrative Proceedings, 86 HARv. L. REv. 1442, 1455-62 (1973). Finkelstein suggests that "a decision-maker should (i) specify the data of such relevance and importance that he finds merits econometric analysis, and (ii) require that data and incorporate other data on a separate basis only when necessary for purposes of accuracy or refinement." $I d$. at 1461.

${ }^{217} 427$ U.S. 495 (1976). 
cluded no dependent children from the benefits, but did conclusively include other children, whether or not they were in fact dependent on the wage earner. ${ }^{218}$ The Court applied a reasonableness test to assess the validity of the presumption.

Whenever members of a specified group are conclusively presumed to meet the criteria governing the allocation of a benefit, however, a discrimination is worked against persons outside that group; "undeserving" members in the group receive the benefit while "undeserving" members outside the group are denied it. In Lucas, nondependent legitimate children received benefits while nondependent illegitimate children did not. This type of discrimination could make the allocation mechanism vulnerable to an equal protection attack, which, in turn, could require the state to demonstrate that its inclusive presumption is clearly and significantly less costly than individualized determinations. Although such an equal protection argument was rejected in Lucas, a similar analysis was applied in Frontiero $v$. Richardson, ${ }^{219}$ a case that can be characterized as rejecting an inclusive presumption. ${ }^{220}$

${ }^{218} I d$. at 498-99.

219411 U.S. 677 (1973).

220 Under the federal law at issue in Frontiero, a member of the uniformed military services with dependents qualifies for an increased "basic allowance for quarters," 37 U.S.C. $\$ 403$ (1970), and comprehensive medical and dental care for the dependents, 10 U.S.C. $\$ 1076(1970)$. Although the wife of a male member of the uniformed services was presumed to be dependent on her husband, whether she was in fact dependent or not, a female member was required to prove her husband's dependence. See 37 U.S.C. $\S 401$ (1970). To satisfy the statutory criterion for dependency, the woman must provide more than one-half of her husband's support. 10 U.S.C. $\S 1072(2)(1970)$. Paralleling the situation in Lucas, nondependent wives received benefits while nondependent husbands did not. The different treatment of dependents according to the sex of the service member nonetheless was invalidated; the classification based on sex triggered a standard of review more rigorous than the reasonableness standard employed in Lucas. Speaking for the Lucas Court, Justice Blackmun asserted that the Frontiero classification received the "strictest scrutiny," 427 U.S. at 509, and could only be justified by "a showing that the Government's dollar 'lost' to overincluded benefit recipients is returned by a dollar 'saved' in administrative expense avoided," 427 U.S. at 509-10. Although the Frontiero plurality ruled that sex classifications are suspect and therefore subject to the closest judicial scrutiny, see 411 U.S. at 682 , a majority of the Court has never adopted such a position, see Kahn v. Shevin, 416 U.S. 351 (1974). Nevertheless, the Court has determined that sex classifications warrant a high standard of equal protection review. See text accompanying notes 83-84 supra.

A similar willingness to apply a higher standard of equal protection review on behalf of illegitimate children would be necessary in order to invalidate the Lucas provision. The Lucas majority argued that the statute involved "does not broadly discriminate between legitimates and illegitimates without more, but is carefully tuned to alternative considerations." 427 U.S. at 513. Justice Stevens' dissent, however, raised substantial questions concerning whether the inclusive presumption rejected in Frontiero was sig- 


\section{Examples of Laws That Survive Conclustve PRESUMPTION REVIEW}

A brief survey of some of the laws that might be challenged as conclusive presumptions will illustrate the principles that confine a conclusive presumption doctrine defined in terms of procedural due process. One set of such laws, the minimum age laws, has already been shown to escape proscription because such laws pursue legitimate substantive objectives. ${ }^{221}$ Courts also would be sensitive to claims that more individualized alternatives to age minimums would impose exceptional administrative burdens. ${ }^{222}$

\section{A. Mandatory Retirement Laws}

At first glance, laws requiring retirement at a specified age appear vulnerable to a conclusive presumption challenge. To the extent that such mandatory retirement laws rest on judgments of job competence, they often could be replaced by appropriate work-related testing and job performance ratings. ${ }^{223}$ Further, not only are feasible methods available for individually determining incompetence, but also the need for those determinations are not likely to occur at an administratively arduous rate. Overall, the kind of determination obviated by an age ceiling is precisely the kind of decision often made in an adjudicatory proceeding and one that appropriately is made on an individualized basis.

Nonprocedural policies, however, may underlie and justify age ceilings. In Massachusetts Board of Retirement v. Murgia, ${ }^{224}$ which upheld Massachusetts' requirement that uniformed state police officers retire at age $50,{ }^{225}$ the state offered nonprocedural explanations in addition to defending its classification on a reasonableness basis. Massachusetts, citing the desirability

nificantly less accurate than the inclusive presumption upheld in Lucas. 427 U.S. at 521-23 (Stevens, J., dissenting).

${ }_{221}$ See text accompanying note 169 supra.

${ }^{222}$ See text accompanying note 213 supra.

${ }^{223}$ See, e.g., Age Discrimination in Employment Act of 1967, 29 U.S.C. \$§ 621-634 (1970 \& Supp. V 1975); Stessin, The Axe and Older Workers, N.Y. Times, June 23, 1974, $\S 3$, at 3 , col. 1 . The argument can be made that the age limit helps to avoid confrontations with older employees who would suffer from individual determinations of incompetence. Some older workers, however, probably suffer more by being forced to abandon gainful employment at a time when continued productive performance is possible. See Stessin, supra.

${ }^{224} 427$ U.S. 307 (1976) (per curiam).

225 Mass. AnN. Laws ch. 32, $\$ 26(3)$ (a) (1973). 
of a rapid promotion schedule, argued before the district court that early retirement boosted the morale of younger state police officers. ${ }^{226}$ Moreover, as a public policy matter-a matter peculiarly within the competence of a legislature to determine-it may be desirable to minimize unemployment among younger workers in order to lessen the occurrence of youthful demoralization and alienation. The age distribution of public employees also has an impact on government expenditures. ${ }^{27}$ New York City officials, for example, recently attempted to jettison older workers as a means for alleviating the city's budget crisis. ${ }^{228}$ In Murgia itself, however, one should note that neither the three-judge federal district court nor the Supreme Court applied or even mentioned conclusive presumption analysis; both evaluated the case under standards of equal protection review. Reversing the district court, which rejected the age limit as failing to satisfy a rational basis test, ${ }^{229}$ the Supreme Court held that the retirement law does rest on a rational basis, ${ }^{230}$ and concluded that the age discrimination and employment opportunity questions presented failed to qualify for a more demanding standard of equal protection review. ${ }^{231}$

Both Justice Marshall's dissent and the district court's opinion in Murgia raise a procedural factor that could save an age ceiling from a conclusive presumption invalidation. They point out that in some situations the measurement and prediction of individual fitness and ability may be extremely difficult or even impossible. ${ }^{232}$ Although measurement problems should not be an excuse for routinely accepting conclusive presumptions, such problems are relevant. In particular, measurement problems deserve close attention when they involve laws designed to protect public safety and health.

For example, although the Murgia district court and Justice Marshall both rejected the Massachusetts age ceiling, they ap-

${ }^{226}$ Murgia v. Massachusetts Bd. of Retirement, 376 F. Supp. 753, 754 (D. Mass. 1974), rev'd, 427 U.S. 307 (1976) (per curiam).

227 Older workers usually have accrued seniority, and so may receive higher wages than younger workers performing the same jobs. See, e.g., 5 U.S.C. $\$ 5332$ (Supp. V 1975).

${ }^{228}$ See N.Y. Times, Dec. 13, 1974, at 1, col. 3; N.Y. Times, Dec. 14, 1974, at 1, col. 2; N.Y. Times, Dec. 18, 1974, at 1, col. 5.

$229376 \mathrm{~F}$. Supp. at $754,756$.

230427 U.S. at $314-17$.

${ }^{231} \mathrm{Id}$. at 312-14.

${ }^{232}$ Id. at 326 n.6 (Marshall, J., dissenting); 376 F. Supp, at 755. 
provingly cited Air Line Pilots Association, International v. Quesada, ${ }^{233}$ which upheld a regulation prescribing retirement for commercial airline pilots at age sixty. The Quesada ruling was considered proper because it rested on a conclusion that the results of physical examinations of pilots age sixty and older lack the desired degree of predictive accuracy. ${ }^{234}$ When the risks associated with inaccurate measurement are high and special measurement problems are presented, as in Quesada, the judicial approval of age ceilings is proper.

The Murgia Court listed important public safety functions performed by the state police, ${ }^{235}$ but made no serious effort to demonstrate that fitness was not adequately measurable after the age of forty-nine. It did mention that an evaluation of a potential cardiovascular failure "would require a detailed number of studies," ${ }^{236}$ but did not argue that such testing would be unreasonably burdensome or that administrative burdens would interfere with the effectiveness of state police programs. Although serious measurement problems involving achievement of public safety goals possibly could have been cited as a procedural justification for the Massachusetts age ceiling, the Murgia decision neither offers nor supports such a defense to a conclusive presumption challenge. The Murgia result, however, can be explained in terms of the nonprocedural objectives asserted by Massachusetts. ${ }^{237}$

\section{B. Protective Regulatory Laws}

Chief Justice Burger has argued that the conclusive presumption doctrine is unjustifiably contrary to the present design of many regulatory statutes and introduces doctrinal difficulties for thousands of state laws. ${ }^{238}$ As an example, he points to the common case where

A State provides that a person may not be licensed to practice medicine or law unless he or she is a graduate of an accredited professional graduate school; a perfectly capable practitioner may as a consequence be

${ }^{233} 276$ F.2d 892 (2d Cir. 1960).

${ }^{234}$ Id. at 898.

${ }^{235} 427$ U.S. at 310.

${ }^{236} \mathrm{Id}$.

${ }^{233}$ See text accompanying notes 224-28 supra.

${ }^{238}$ See, e.g., Vlandis v. Kline, 412 U.S. 441,442 (1973) (Burger, C.J., dissenting). 
barred "permanently and irrebuttably" from pursuing his calling, without ever having an opportunity to prove his personal skill. ${ }^{239}$

A conclusive presumption doctrine defined in terms of appropriate procedural principles should allay the Chief Justice's fears. In the medical licensing situation presented above, denial of individualized competency determinations to persons who have not attended medical school, but who nonetheless claim adequate medical competence, properly serves the legislative policy of licensing doctors in accordance with highly protective standards. The state might reasonably determine that graduation from a medical school assures at least a minimum level of medical skill, knowledge, experience, maturity, and good judgment and that there is no alternative objective test that adequately measures these qualities. Under such circumstances, and in order to protect the health and safety of the state's citizens, the state reasonably could require all doctors practicing within its borders to graduate from medical school. Given these public health and safety objectives of a medical licensing system, the state should not be required to implement testing procedures of questionable accuracy in measuring the relevant criteria. ${ }^{240}$

This approach was evident in Weinberger $\%$. Hynson, Wescott and Dunning, Inc. ${ }^{241}$ in which the Court upheld a drug licensing program administered by the Food and Drug Administration (FDA) under the 1962 amendments to the Federal Food, Drug, and Cosmetic Act of 1938. ${ }^{242}$ That law directs the FDA to deny the approval required to bring a new drug onto the market unless "substantial evidence" of the drug's effectiveness was supplied. ${ }^{243}$. The Commissioner of the FDA issued a series of regulations setting threshold standards for "adequate and wellcontrolled investigations," which, under the statute, comprised "substantial evidence."244 Investigations not satisfying these standards were disallowed as evidence of drug effectiveness; if an applicant presented no evidence that "on its face" met the

$239 I d$.

${ }^{241}$ See text accompanying notes 232-34 supra. Moreover, a state's judgment about the reliability of such testing is especially deserving of deference since medical graduation requirements do not permanently bar access to the practice of medicine.

241412 U.S. 609 (1973).

24221 U.S.C. $\$ \S 301-392$ (1970).

24321 U.S.C. $\$ 355$ (d) \& (e) (1970 \& Supp. V 1975).

24421 U.S.C. § 355(d) (1970). 
prescribed standards, the application was rejected without an opportunity to present alternative evidence. ${ }^{245}$

The same type of considerations that favored judicial deference in the medical licensing situation were present in Hynson. The FDA, in pursuit of its statutory directives, administers broad public health and safety measures. ${ }^{246}$ Its reasonable judgments concerning the reliability of different types of evidence should be upheld by the courts. Even though the FDA regulations at issue in Hynson can be viewed as denying applicants a more individualized factual review, they differ significantly from the government practices examined in the conclusive presumption cases. By using its evidentiary threshold rules, the FDA is not confining its inquiry to certain factual presentations as a mere shortcut to avoid reviewing a broader array of relevant factors; rather, as the Court recognized, the conclusive "standard of 'well controlled investigations' particularized by the regulations is a protective measure designed to ferret out those drugs for which there is no affirmative, reliable evidence of effectiveness."

In other cases involving regulatory threshold judgments, factfinding in the Goldberg sense is not in question. In United States $v$. Storer Broadcasting, ${ }^{248}$ the Supreme Court allowed the FCC by rule to preclude additional licensing for an applicant who exceeded the FCC's limitation on multiple radio and TV station ownership. Likewise, in Federal Power Commission $v$. Texaco, ${ }^{249}$ the Court upheld an FPC rule automatically rejecting an independent natural gas producer's application for permission to supply natural gas to a pipeline if the submitted contract contained proscribed pricing provisions. Both the FCC and FPC administer broad public interest statutory standards. ${ }^{250}$ Unlike the factfinding process in the conclusive presumption and fair adjudication cases, these agency determinations do not involve the application of objective standards. Instead, the threshold requirements in Storer and Texaco represent administrative transla-

245412 U.S. at 620.

${ }^{246} I d$. at 622.

247 Id.

248351 U.S. 192 (1956).

249377 U.S. 33 (1964).

${ }^{250}$ The Federal Power Commission makes determinations concerning the transportation and sale of natural gas by applying a "public convenience and necessity" standard. 15 U.S.C. $\$ 717 \mathrm{f}$ (c) (1970). In awarding broadcast licenses, the Federal Communications Commission determines how the "public convenience, interest, or necessity" will be served. 47 U.S.C. $\$ 307$ (a) (1970). 
tions of general statutory commands into more specific policy priorities. In Texaco, Justice Douglas expressly recognized this policy-making function as he described the FPC establishment of thresholds as "particularizing statutory standards through the rule-making process." 251

\section{Fund Allocation Decisions}

Jefferson $\%$. Hackney ${ }^{252}$ exemplifies a type of funding allocation that escapes the individualized determination requirement. In Jefferson, Texas recipients of Aid to Families With Dependent Children (AFDC) ${ }^{253}$ challenged the legality of the less favorable welfare treatment they received relative to the aid given recipients of Old Age Assistance (OAA), ${ }^{254}$ Aid for the Permanently and Totally Disabled (APTD), ${ }^{255}$ and Aid to the Blind (AB). ${ }^{256}$ The Texas welfare scheme subsidized AFDC families to an amount equal to seventy-five percent of their statutorily defined needs while subsidizing $\mathrm{OAA}, \mathrm{APTD}$, and $\mathrm{AB}$ recipients to amounts equaling ninety-five percent of need or higher. ${ }^{257}$ The Supreme Court upheld the lower subsidy for AFDC families because Texas could reasonably decide that

the aged and infirm are the least able of the categorical grant recipients to bear the hardships of an inadequate standard of living. While different policy judgments are of course possible, it is not irrational for the State to believe that the young are more adaptable than the sick and elderly, especially because the latter have less hope of improving their situation in the years remaining to them. ${ }^{258}$

Legislative policy decisions about which groups to benefit-and to what extent-generally are reviewed under the permissive equal protection standard of reasonableness. If, for

251377 U.S. at 39.

252406 U.S. 535 (1972).

${ }^{253} 42$ U.S.C. $\$ \S 601-644$ (1970), as amended by 42 U.S.C. $\$ \S 601-644$ (Supp. V 1975).

25442 U.S.C. $\$ \S 301-306$ (1970), as amended by 42 U.S.C. $\$ \S 301-306$ (Supp. V 1975).

25542 U.S.C. $\$ \S 1351-1355$ (1970), as amended by 42 U.S.C. $\$ \$ 1351-1355$ (Supp. V 1975).

25642 U.S.C. $\S \S 1201-1206$ (1970), as amended by 42 U.S.C. $\S \S 1351-1355$ (Supp. V 1975).

257406 U.S. at 537 n.3.

${ }^{258}$ Id. at 549; see Dandridge v. Williams, 397 U.S. 471,487 (1970). 
example, a legislature were required to distribute equally aid to all OAA, APTD, and AB beneficiaries and AFDC households that could demonstrate commensurate need, the contemporary political process would be substantially altered. Legislative action favoring groups on moral, political, or fiscal policy grounds would not be possible. ${ }^{259}$ In any case, the legislative concept of relative need as a basis for allocating welfare funds may not be amenable to the kind of adjudicatory factual determination found necessary in the cases invalidating conclusive presumptions. How does one refute the legislative determination that the indigent disabled, blind, and aged are needier than indigent families headed by females? The Texas assistance statutes do not provide an objective basis for making this kind of determination.

The conclusive presumption doctrine does not address statutory provisions that embody legislative policy judgments concerning nonprocedural objectives like the allocation of limited resources. Instead, it deals with provisions aimed at avoiding individualized determinations of statutory coverage. ${ }^{260}$ The statutory distinction in Jefferson, for example, should escape conclusive presumption scrutiny because it is based on the kind of policy judgment a legislature is expected to make; it is not a legislative effort to avoid individualized procedures for determining need.

By contrast, the provision of the Food Stamp Act invalidated in Murry did not embody the same kind of allocation decision. ${ }^{261}$ Congress did not decide that all households with members 18 years or older who were claimed as tax dependents by individuals outside the household were not in need of food stamps, regardless of whether the tax dependents actually received outside income. Instead, Congress intended to deny food stamps to households adequately supported by outside income. Despite the very individualized nature of this goal, the statute avoided specific determinations of which households were ineligible by use of a broad presumption. Such an administrative short cut can be challenged-and in this case rejected-by a procedureoriented conclusive presumption analysis.

\section{Land-Use Restrictions}

Another type of statute that survives conclusive presump-

${ }^{259}$ See 406 U.S. at 548-49.

26" See text accompanying notes $118-87$ supra.

261 See text accompanying notes 49-51 supra. 
tion scrutiny is the zoning ordinance upheld in Village of Belle Terre v. Boraas. ${ }^{262}$ That ordinance permitted as inhabitants of Belle Terre only households of "persons related by blood, adoption, or marriage" or of no more than two persons "living and cooking together as a single housekeeping unit though not related by blood, adoption, or marriage." 263

The Belle Terre ordinance, apparently designed to ban large "households" of college students, was defended as a reasonable means of limiting noisy lifestyles and increased traffic congestion. ${ }^{264}$ Indeed, the theory that a zoning authority anticipates nuisances and then precludes or controls them by regulating land uses provides a doctrinal justification for the creation of land-use zones and a defense against claims of improper deprivation of property rights. ${ }^{265}$ To be sure, Belle Terre might have avoided these nuisances more discriminatingly by making individualized determinations of household behavior; its ordinance escapes conclusive presumption reversal, however, because zoning practice has grown beyond its nuisance roots. There is a general acceptance of a role for zoning that transcends individualized nuisance-type determinations. Many view zoning regulation as a legitimate means for a local government to implement its vision of a better community. ${ }^{266}$ Thus, writing for the Court in Belle Terre, Justice Douglas claimed that the ordinance preserved the attractiveness of the community for families. ${ }^{\mathbf{2 6 7}}$ Regardless of whether family zones are quieter and enjoy reduced vehicular traffic, some families may prefer to live in a neighborhood where all the other households are similarly struc-

262416 U.S. 1 (1974).

${ }^{263} I d$. at 2.

264 Id. at 9.

${ }^{265}$ See Village of Euclid v. Ambler Realty Co., 272 U.S. 365, 386-90 (1926). See generally Ackerman, Impact Statements and Low Cost Housing, 46 S. CAL. L. REv. 754 (1973); Kleven, Inclusionay Ordinances-Policy and Legal Issues in Requiring Private Developers to Build Low Cost Housing, 21 U.C.L.A. L. Rev. 1432, 1493-96 (1974); Lefcoe, The Public Housing Referendum Case, Zoning, and the Supreme Court, 59 CaL. L. Rev. 1384, 1443-44 (1971).

${ }^{266}$ For examples of decisions thoughtfully evaluating zoning ordinances defended in terms of community preservation and environmental goals, see Steel Hill Dev., Inc. v. Sanbornton, 469 F.2d 956 (1st Cir. 1972); Southern Burlington County NAACP v. Township of Mount Laurel, 67 N.J. 151, 336 A.2d 353 (1971), appeal dismissed, 423 U.S. 808 (1975); National Land \& Investment Co. v. Kohn, 419 Pa. 504, 215 A.2d 597 (1965).

${ }^{267} 416$ U.S. at 9. Another nonprocedural objective expressed in Belle Terre was stabilization of the community's rent structure. See 416 U.S. at 18 (Marshall, J., dissenting). In some cases this substantive goal alone might be reason enough to limit college student access to community housing. 
tured. An individualized determination requirement for all land-use regulations would seriously frustrate the attempt to serve such abstract "family values." 268 Comprehensive land-use planning, expressing policy judgments and aimed at fostering a particular community character, would flounder on a requirement of individualized adjudications. ${ }^{269}$

\section{E. Classifications by Sex}

In Kahn $\%$. Sherin, ${ }^{270}$ the Supreme Court upheld a Florida law providing a $\$ 500$ per year property tax exemption for widows, but not for widowers. Generally, tax preference provisions escape conclusive presumption scrutiny because a substantive objective is readily discernible. A tax break for farmers, for example, might be aimed at encouraging greater agricultural production. In a nonincentive area such as tax aid for the blind, the preference serves as partial compensation for a handicap. In a sense, the Court upheld the Florida tax law as compensation for the economic disadvantage in being female. ${ }^{271}$ Justices Brennan and Marshall, dissenting, agreed that the tax break served a legitimate remedial purpose. ${ }^{272}$

In spite of substantive justifications, the statute is subject to procedural challenge for improperly dispensing with individual determinations of which widows are in fact economically disadvantaged because of their sex. The law, however, does not provide objective standards for individually determining sex-based economic disadvantage. Just as in the case of income limits serving as standards for allocating social welfare subsidies, ${ }^{273}$ judicial reversal for failure to use individualized determinations would require the legislature not only to establish a procedure, but also to make substantive judgments concerning how to fashion objective standards for identifying sex-based economic disadvantage.

$268 I d$.

${ }^{269}$ Satisfying a conclusive presumption test obviously would not save the Belle Terre ordinance from proscription on other grounds. Although a wealth of material analyzing zoning schemes that restrict the access of certain groups to suburban communities existed, the Court's opinion ignored the issues raised in the literature. For a critical examination of restrictive zoning practices, see Ackerman, The Mount Laurel Decision: Expanding the Boundaries of Zoning Reform, 1976 U. ILL. L.F. 1; Ellickson, Alternatives to Zoning: Covenants, Nuisance Rules, and Fines as Land Use Controls, 40 U. CHI. L. REv. 681 (1973); id. 703 n.83, 704 n.89 (collecting sources).

270416 U.S. 351 (1974).

271 Id. at 353-55.

${ }^{272}$ Id. at 358-59 (Brennan, J., dissenting).

${ }^{273}$ See text accompanying notes 252-61 supra. 
Consequently, the provision is not subject to a conclusive presumption review. Moreover, even if the requisite standards were provided, the Florida law could only be characterized as an inclusive presumption. These generally are reviewed under permissive standards. ${ }^{274}$

\section{CONCLUSION}

Fearing that the conclusive presumption doctrine would become "a virtual engine of destruction for countless legislative judgments" 275 and unable to discern limiting principles sufficient to hold the doctrine to manageable proportions, the Supreme Court rejected conclusive presumption analysis in Salfi. An examination of the underlying principles of the doctrine and how it has been applied, however, reveals that it properly can be confined to cases involving unfair adjudicatory practices. Thus, when a statute or rule is construed or defended as primarily serving a procedural purpose, and when either the statute or rule itself or judicial or administrative tradition presents discrete, objective criteria recognized and understood by the affected parties, then conclusive presumption review provides a means for assuring some minimal level of procedural fairness. Defined in these terms, this procedural doctrine limits fair adjudication requirements to those situations in which one usually expects to find individualized factfinding.

At the hazy margin of due process, the procedural analysis prevents legislatures and agencies from abusing their broad powers of classification; it forbids classifications defined by presumed facts that can and should be determined on an individualized basis. Yet the doctrine does not disregard the impact of procedural requirements on legislative and administrative programs, for even when a conclusive presumption review is appropriate it does not uncompromisingly require an individualized determination. Consistent with the Goldberg approach to due process analysis, the doctrine can accommodate valid substantive objectives by accepting reduced procedures. A survey of the fair adjudication rulings provides many examples of procedural safeguards that have been fashioned to accommodate valid substantive goals. As one court aptly stated, a procedural fairness review must be sufficiently flexible to ensure program

${ }^{274}$ See text accompanying notes $217-20$ supra.

${ }^{275}$ Weinberger v. Salfi, 422 U.S. 749,772 (1975). 
viability "lest we kill the goose in our solicitude for the eggs."276 In Turner, the Supreme Court reintroduced the conclusive presumption test, apparently as an adjunct to the new reasonableness variation of equal protection analysis. Certainly, the identification of a special interest provides an appropriate occasion for requiring legislatures and agencies to act with greater precision. Pointing to an "unpredictable" Court ${ }^{277}$ and "ad hoc elevation of rights and values," 278 however, critics have suggested that such interests are only uncertainly safeguarded. ${ }^{279}$ More significantly, special interest and new reasonableness principles are unlikely to provide the desirable protection mandated by the application of procedural principles to cases like Murry (the food stamp eligibility case) and Mandina (the housing eligibility case). For example, it is not easily demonstrable that the eligibility criterion invalidated in Murry is any less reasonable than that upheld in Salfi. Also, current equal protection treatment of housing and poverty issues does not offer a basis for correcting the procedural deficiency in Mandina. ${ }^{281}$ Thus, a con-

${ }^{276}$ Hahn v. Gottlieb, 430 F.2d 1243, 1246 (1st Cir. 1970).

${ }^{277}$ Forum: Equal Protection and the Burger Court, 2 HAST. Const. L.Q. 645, 664 (1975) (remarks of Prof. Gunther).

${ }^{278}$ Wilkinson, The Supreme Court, The Equal Protection Clause, and the Three Faces of Constitutional Equality, 61 VA. L. REv. 945, 946 (1975).

${ }^{279}$ See, e.g., Forum: Equal Protection and the Burger Court, supra note 277, at 648 (remarks of Prof. Forrester), 656-57 (remarks of Prof. Gunther); Wilkinson, supra note 278, at 950-54.

280 Although a procedural review easily mandated the fair procedures required in Mandina, current equal protection doctrine would not so easily yield the same sensible result. In Lindsey v. Normet, 405 U.S. 56 (1972), the Supreme Court rejected as unreasonable an Oregon statute, ORE. Rev. STAT. $\$ 105.160(1969)$, that required a tenant seeking to appeal an eviction after a forcible entry and wrongful detainer (FED) action brought by the landlord to post a bond equal to twice the rental value of the property from the time of commencement of the action to final judgment. 405 U.S. at 74. This part of the Normet decision and Mandina both can be viewed as involving special poverty and housing values. However, in an earlier portion of the Normet ruling, which rejected an attack on Oregon's FED procedures, ORE. Rev. STAT. $\$$ 105.135, .140, .145 (1969), the majority opinion declared that the Constitution provides no "guarantee of access to dwellings of a particular quality . .." 405 U.S. at 74. Although the discussion of the double-bond requirement did speak of its "discrimination against the poor," id. at 79, the Normet Court's primary concern apparently was that the double-bond requirement unfairly precluded some litigants from exercising the statutorily created right to appeal. Id. at 77-79. The Mandina facts, however, would not give rise to such a judicial interest in preserving a fair appeals process. If a Mandina "new reasonableness" claim were to be grounded on a poverty-oriented argument, its failure would be certain in light of the Supreme Court's rulings in such cases as James v. Valtierra, 402 U.S. 137 (1971) and San Antonio Ind. School Dist. v. Rodriguez, 411 U.S. 1 (1973). An argument invoking both poverty and housing interests also would be unlikely to succeed. See James v. Valtierra, 402 U.S. 137 (1971). See also Village of Belle Terre v. Boraas, 416 U.S. 1 (1974); Lindsey v. Normet, 405 U.S. at 73-74 (discussing possible constitutional status for hous- 
clusive presumption theory that invokes procedural protections only on behalf of judicially defined special interests would leave intact many laws and regulations that improperly eschew a fair degree of individualized determination.

Had the Court appreciated the analytic boundaries that constrain the procedural reach of the conclusive presumption doctrine in Salfi, it might have ordered a more individualized determination. As Justice Brennan explained in dissent, objective standards for conducting adjudicatory factfinding were discernible. ${ }^{281}$ A requirement of fair adjudication in Salfi and other cases like it would not involve the courts in policy judgments, play havoc with a broad range of commonly accepted laws, or mask substantive intervention with procedural dress. It merely would be a judicial exercise of a peculiarly judicial functionensuring procedural fairness, regardless of the position of the individual interest affected on the Court's current hierarchy of values. In a classic formulation, it was observed that

[p]rocedural fairness, if not all that originally was meant by due process of law, it is at least what it most uncompromisingly requires. Procedural due process is more elemental and less flexible than substantive due process. It yields less to the times, varies less with conditions, and defers much less to legislative judgment. Insofar as it is technical law, it must be a specialized responsibility within the competence of the judiciary on which they do not bend before political branches of the Government, as they should on matters of policy which comprise substantive law. ${ }^{282}$

A properly defined conclusive presumption doctrine can help ensure the use of fair procedures in pursuit of government's legitimate substantive goals.

ing interests). Moreover, even if Mandina affected the same values that lead to the Court's invalidation of the double-bond requirement in Normet, the Court still might determine under a new reasonableness test that the rent-income ratio screening standard at issue in Mandina more reasonably served a legitimate objective than did the Oregon doublebond requirement.

281422 U.S. at 804 (Brennan, J., dissenting).

282 Shaughnessy v. United States ex rel. Mezei, 345 U.S. 206, 224 (1953) (Jackson \& Frankfurter, J.J., dissenting). Justice Jackson's dissent was specifically endorsed in a separate opinion by Justices Black and Douglas. Id. at 217 (Black \& Douglas, J.J., dissenting). 